\title{
Aldol Condensation and Esterification over Ti-Substituted *BEA Zeolite: Mechanisms and Effects of Pore Hydrophobicity
}

\author{
Supporting information
}

Zhongyao Zhang ${ }^{1,2, \dagger}$, Claudia E. Berdugo-Díaz ${ }^{2, \dagger}$, Daniel T. Bregante ${ }^{2}$, Hongbo Zhang ${ }^{2}$, and David W. Flaherty ${ }^{1,2 *}$

${ }^{1}$ DOE Center for Advanced Bioenergy and Bioproducts Innovation, Urbana, Illinois, 61801, (USA)

${ }^{2}$ Department of Chemical and Biomolecular Engineering, University of Illinois at Urbana-Champaign, Urbana, Illinois, 61801, (USA)

†Contributed equally

*Corresponding Author

Phone: (217) 244-2816

Email: dwflhrty@illinois.edu 


\section{S1.0. Additional Catalyst Characterization}

\section{S.1.1. X-ray Diffractograms and Tauc Plots for All Ti-BEA}
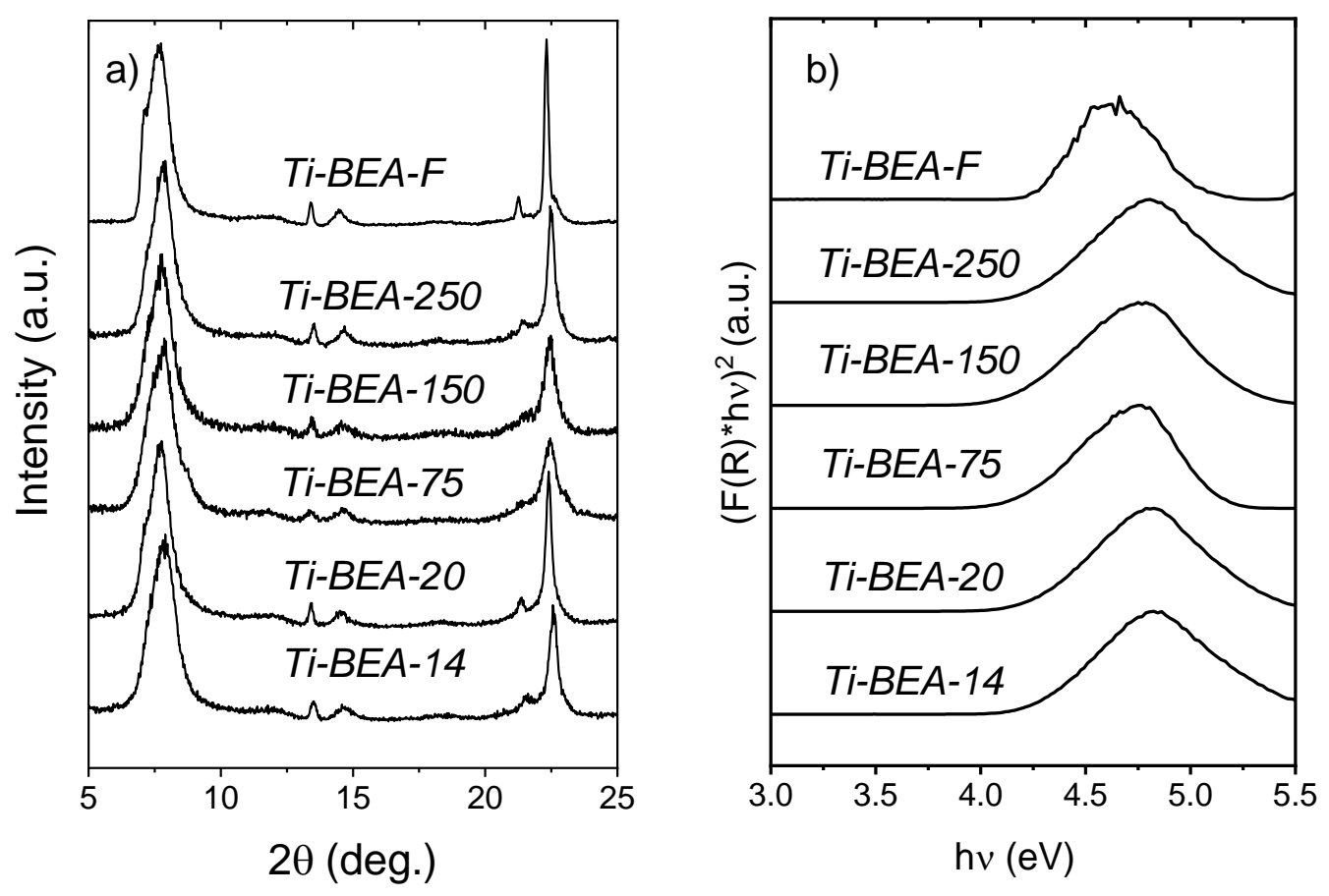

Figure S1. (a) X-ray diffractograms for all Ti-BEA. Diffractograms are vertically offset for clarity. ${ }^{1}$ Materials previously synthesized and reported in Bregante et.al [JACS, 2019, 141, 7302 - 7319.]) (b) Tauc plots for all Ti-BEA. The plots are normalized to the intensity of the feature at $\sim 4.6 \mathrm{eV}$ and are vertically offset for clarity. ${ }^{1}$ Materials previously synthesized and reported in Bregante et.al [JACS, 2019, 141, 7302 - 7319.])

Ti-BEA materials contain crystallographic features that correspond to BEA frameworks. Figure S1a shows X-ray diffractograms for all Ti-BEA catalysts with characteristic feature at $\sim 22.4$ degree that indicates high-degree of crystallinity of BEA materials. This feature is sharpest for Ti-BEA-F and broader for other materials due to internal defects formed from dealumination treatments. ${ }^{1}$ Additionally, there is no observable feature for oligomeric $\mathrm{TiO}_{\mathrm{x}}$ species (e.g., anatase $\mathrm{TiO}_{2}$ ). Figure $\mathbf{S 1 b}$ shows the UV-vis spectra for all Ti-BEA catalysts. The band gap of these materials can be evaluated by the $\mathrm{x}$-intercepts that are fit through extrapolation. $\mathrm{Bulk}^{\mathrm{TiO}} 2$ typically shows band gap at $\sim 3.2 \mathrm{eV}$. Band gaps of Ti-BEA range from 4.2 to $4.3 \mathrm{eV}$, which indicates highly dispersed Ti atoms incorporated into BEA frameworks. ${ }^{1}$ 


\section{S.1.2. Raman Spectra for All Ti-BEA}
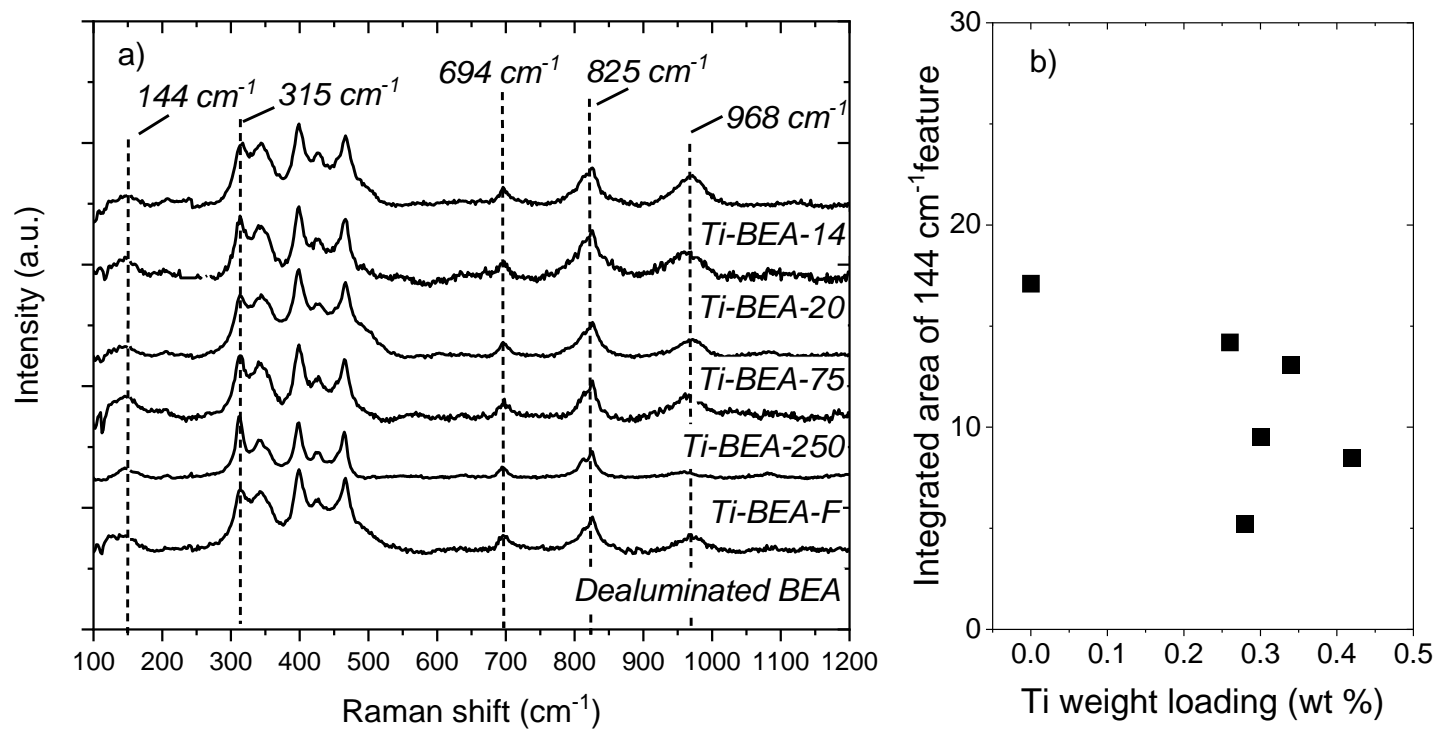

Figure S2. (a) Ex situ Raman spectra of Ti-BEA and dealuminated BEA-20 (initial Si/Al $=20$ ). All spectra are taken at ambient conditions with a Raman spectrometer (Renishaw, InVia) equipped with a $532 \mathrm{~nm}$ laser that delivered a fixed power density $\left(2 \mathrm{~mW} \mu \mathrm{m}^{-2}\right)$. Spectra represent the average of 10 scans each acquired with an accumulation time of 2 seconds. Spectra are normalized by the peak at $315 \mathrm{~cm}^{-1}$ (a characteristic vibrational mode of the BEA framework), and vertically offset for clarity. (b) Integrated areas for the Raman peak at $144 \mathrm{~cm}^{-1}$ for Ti-BEA catalysts and dealuminated BEA-20 as a function of the measured Ti weight loading.

Figure S2a shows ex situ Raman spectra for dealuminated BEA-20 (initial Si/Al = 20), which does not contain Ti, and for the series of Ti-BEA catalysts. All spectra are normalized by the feature at $315 \mathrm{~cm}^{-1}$ that reflects vibrational modes of the 5-member rings of the $\mathrm{BEA}$ framework. ${ }^{2}$ Oligomeric $\mathrm{TiO}_{\mathrm{x}}$ and anatase $\mathrm{TiO}_{2}$ possess a strong feature at $144 \mathrm{~cm}^{-1}$ used as a sensitive method to detect these structures,,$^{2-3}$ and this peak is hardly observable in Raman spectra for the Ti-BEA materials (Fig. S2a). Figure S2b presents integrated areas for the peak near $144 \mathrm{~cm}^{-1}$ in Raman spectra for all BEA materials and demonstrates that the area of this feature does not vary significantly among dealuminated BEA-20 and Ti-BEA catalysts. Notably, this peak area is greatest for the dealuminated BEA-20 which suggests that the small feature observed does not signify $\mathrm{TiO}_{\mathrm{x}}$ in extraframework positions but instead results from modes inherent to BEA or appears as an artifact from the baseline subtraction. There are several peak ranging from 315 to $500 \mathrm{~cm}^{-1}$ that correspond to BEA frameworks including 4-member, 5-member and 6-member rings. ${ }^{2}$ The peak at $694 \mathrm{~cm}^{-1}$ corresponds to the BEA framework, because this peak also appears on dealuminated BEA zeolites. Select earlier studies attributed this feature to amorphous $\mathrm{TiO}_{\mathrm{x}}$ structures in zeolites (e.g., penta- and hexa-coordinated $\mathrm{Ti}$ species). ${ }^{3-4}$ Alternatively, other publications also reported the feature at $694 \mathrm{~cm}^{-1}$ on hydrothermally synthesized BEA zeolites, which suggests this feature could also be related to BEA frameworks. ${ }^{2,5}$ The disagreements in literature are worth attention for interpretation of this specific Raman feature. The feature centering at $825 \mathrm{~cm}^{-1}$ corresponds to symmetric skeletal modes of silicates, and the one centering at $968 \mathrm{~cm}^{-1}$ corresponds to Ti atoms that are incorporated into zeolite frameworks or defects related to silanols (i.e., $\left.\mathrm{O}_{3} \mathrm{Si}-\mathrm{OH}\right) .{ }^{2-4,}{ }^{6}$ Collectively, these results suggest there are no spectroscopically observable $\mathrm{TiO}_{x}$ oligomers or anatase $\mathrm{TiO}_{2}$ nanoparticles on the synthesized Ti-BEA catalysts. Hence, the Ti atoms presumably reside at frameworks positions within the BEA zeolites. 


\section{S.1.3. Infrared Spectra of Ti-BEA at Dehydrated and Ambient Conditions}
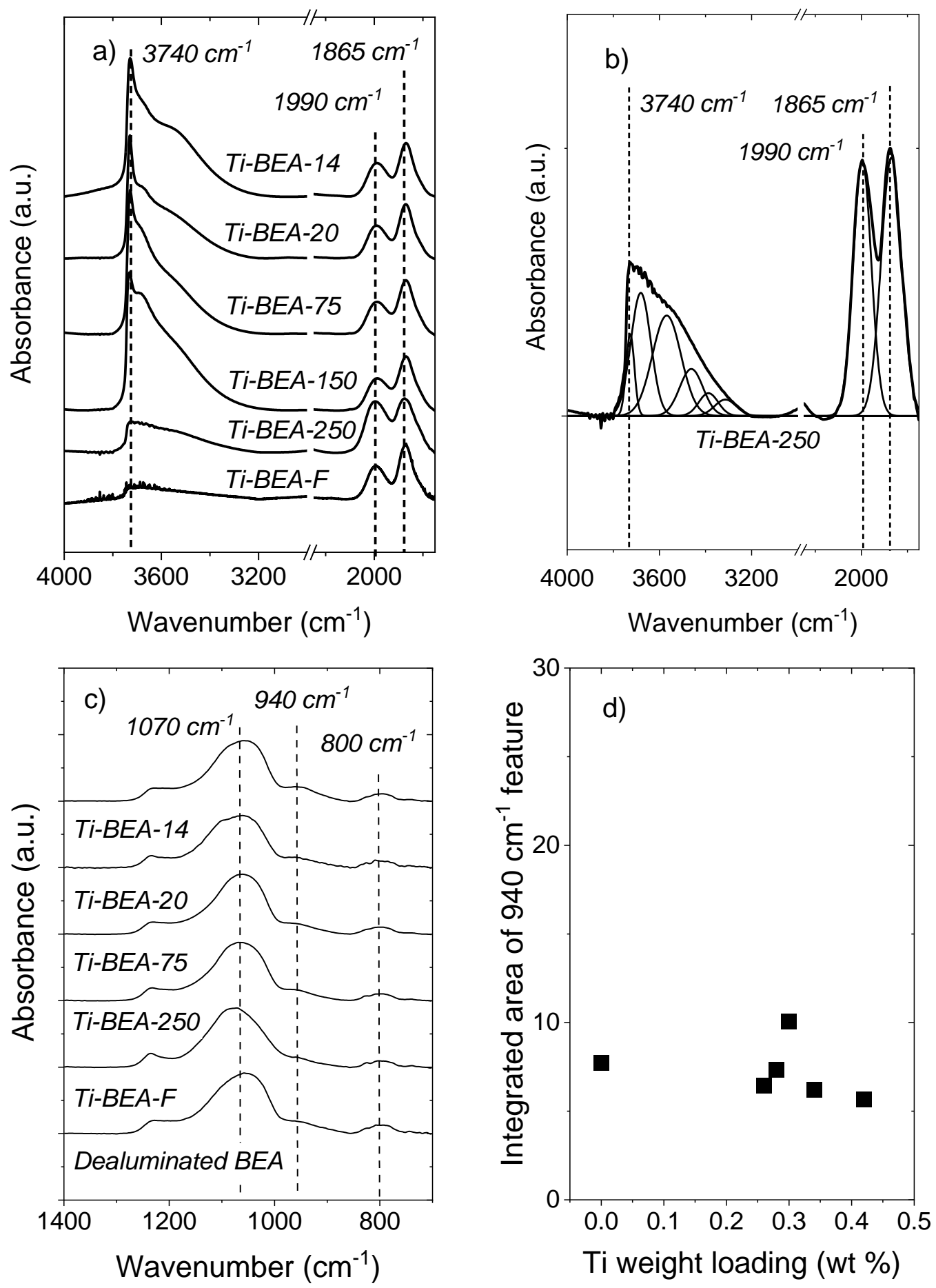

Figure S3. (a) Infrared spectra of Ti-BEA catalysts $\left(50 \mathrm{~cm}^{3} \mathrm{~min}^{-1} \mathrm{He}, 573 \mathrm{~K}\right.$, by Fourier transform infrared spectrometer (Bruker, Tensor 37)). All spectra are normalized to the $v\left(\mathrm{Si}-\mathrm{O}-\mathrm{Si}\right.$ ) overtone at $1865 \mathrm{~cm}^{-1}$, assumed to have a constant extinction coefficient for all Ti-BEA. Spectra are vertically offset for clarity. (b) Peak fitting for raw Ti-BEA-250 spectrum. Six gaussian peaks were applied to fit $v(\mathrm{O}-\mathrm{H})$ feature. Two gaussian peaks were applied to fit $v(\mathrm{Si}-\mathrm{O}-\mathrm{Si})$ overtones. (c) Ex situ infrared spectra of Ti-BEA catalysts and dealuminated BEA-20 (initial Si/Al $=20$ ) 
at ambient conditions using an ATR-IR spectrometer (Bruker, ALPHA). All spectra are normalized to the $v(\mathrm{O}-\mathrm{Si}-\mathrm{O})$ mode at $1070 \mathrm{~cm}^{-1}$ and vertically offset for clarity. (d) Integrated areas for the infrared feature at $940 \mathrm{~cm}^{-1}$ for Ti-BEA catalysts and dealuminated BEA-20 as a function of the measured Ti weight loading.

In the main text, Figure 1 shows the spectra of infrared spectra of Ti-BEA-14, Ti-BEA-20, Ti-BEA-150 and Ti-BEA$\mathrm{F}$ at $573 \mathrm{~K}$ while He is purging. Here Figure S3a shows the spectra of all Ti-BEA catalysts at the same conditions. Figure S3b shows an example of peak fitting for Ti-BEA-250. Six gaussian peaks were applied to fit $v(\mathrm{O}-\mathrm{H})$ feature ranging from 3300 to $3750 \mathrm{~cm}^{-1}$, and the sharp peak fit at $3740 \mathrm{~cm}^{-1}$ corresponds to isolated silanols. The other five gaussian peaks represent hydrogen-bonded silanol nests (e.g., $\left.(\mathrm{SiOH})_{4}\right)$, the areas of which are sum for $A_{(\mathrm{SiOH})_{4}} \cdot v\left(\mathrm{Si}_{-}\right.$ $\mathrm{O}-\mathrm{Si}$ ) overtones are fit by two gaussian peaks centering at 1865 and $1990 \mathrm{~cm}^{-1}$ that count for $A_{(S i-O-S i)}$. Silanol density is calculated by this equation:

$$
\phi_{I R}=\frac{A_{(\mathrm{SiOH})_{4}}}{A_{(\mathrm{Si}-\mathrm{O}-\mathrm{Si})}}
$$

The calculated $\phi_{I R}$ values vary with parent silica to aluminum ratio and synthesis methods and are shown in Table $\mathbf{1}$ in the main text.

Figure S3c shows ex situ the attenuated total reflection infrared spectra of Ti-BEA catalysts and dealuminated BEA20. Previous literature reported Ti atoms that are incorporated into the framework of MFI zeolites (i.e., TS-1) can present a characteristic feature at $\sim 970 \mathrm{~cm}^{-1}$, which can be used to semi-quantitatively characterize the Ti sites in zeolite frameworks. ${ }^{3}$ The features centering at $1070 \mathrm{~cm}^{-1}$ and $800 \mathrm{~cm}^{-1}$ correspond to asymmetric and symmetric stretching mode of tetrahedral Si sites. ${ }^{7}$ Here, a peak is evident as a shoulder near $940 \mathrm{~cm}^{-1}$, which may be postulated to reflect Ti atoms incorporated into the framework based on prior literature. Figure S3d shows peak areas of the features at $940 \mathrm{~cm}^{-1}$ and these peak areas do not vary significantly from dealuminate BEA to Ti-BEA catalysts. The weight loading of the Ti-BEA materials reported here is approximately $0.3 \mathrm{wt} \%$ while the weight loading for the reported TS-1 and other materials that clearly show features at $970 \mathrm{~cm}^{-1}$ are typically 10 -fold or more greater (e.g., 3 - $4 \mathrm{wt} \%){ }^{3}$ Consequently, these results (Fig. S3d) suggest the lack of feature attributable to framework Ti atoms stems from the low Ti content of these materials. Therefore, infrared spectra of Ti-BEA cannot be used as direct evidence that Ti resides in the framework of BEA zeolites. Despite the absence of evidence from this form of characterization, the other forms of spectroscopic, chemical, and catalytic characterization described here and in prior publications from our group verify the existence of these Ti active sites. ${ }^{1}$ 


\section{S.2.0. Additional Kinetic Data}

\section{S.2.1. Turnover Rate of Aldol Condensation and Esterification as Functions of Pressure of $\mathrm{CH}_{3} \mathrm{CHO}$, $\mathrm{C}_{2} \mathrm{H}_{5} \mathrm{OH}$ and $\mathrm{H}_{2} \mathrm{O}$}
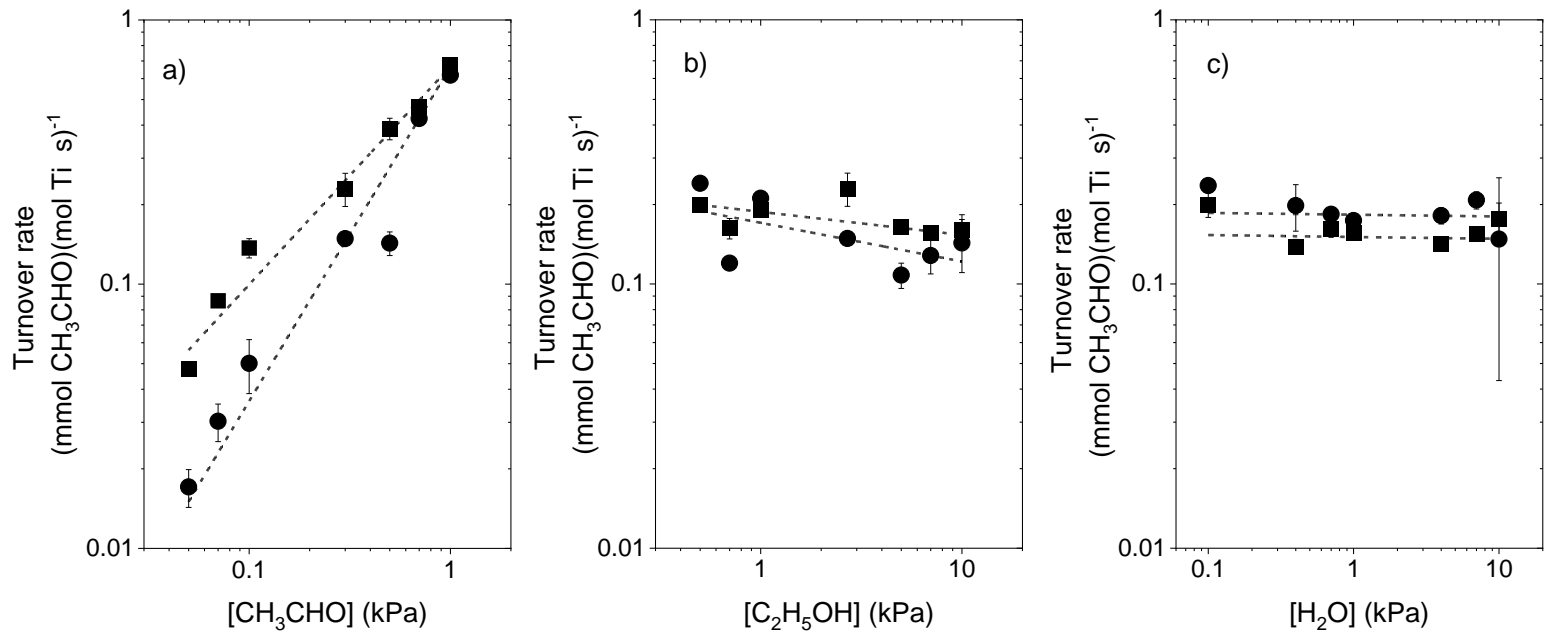

Figure S4. Turnover rate for aldol condensation as functions of the pressure of (a) $\mathrm{CH}_{3} \mathrm{CHO}\left(2.7 \mathrm{kPa} \mathrm{C}_{2} \mathrm{H}_{5} \mathrm{OH}, 15\right.$ $\mathrm{kPa} \mathrm{H}$ ), (b) $\mathrm{C}_{2} \mathrm{H}_{5} \mathrm{OH}\left(0.3 \mathrm{kPa} \mathrm{CH}_{3} \mathrm{CHO}, 15 \mathrm{kPa} \mathrm{H}_{2}\right)$; and of (c) $\mathrm{H}_{2} \mathrm{O}\left(0.3 \mathrm{kPa} \mathrm{CH}_{3} \mathrm{CHO}, 0.6 \mathrm{kPa} \mathrm{C}_{2} \mathrm{H}_{5} \mathrm{OH}, 15 \mathrm{kPa} \mathrm{H}_{2}\right)$ upon Ti-BEA-75 ( $)$ and Ti-BEA-250 ( catalysts at $503 \mathrm{~K}$. Dashed lines represent fits to functional forms of the rate expressions in Table 1.
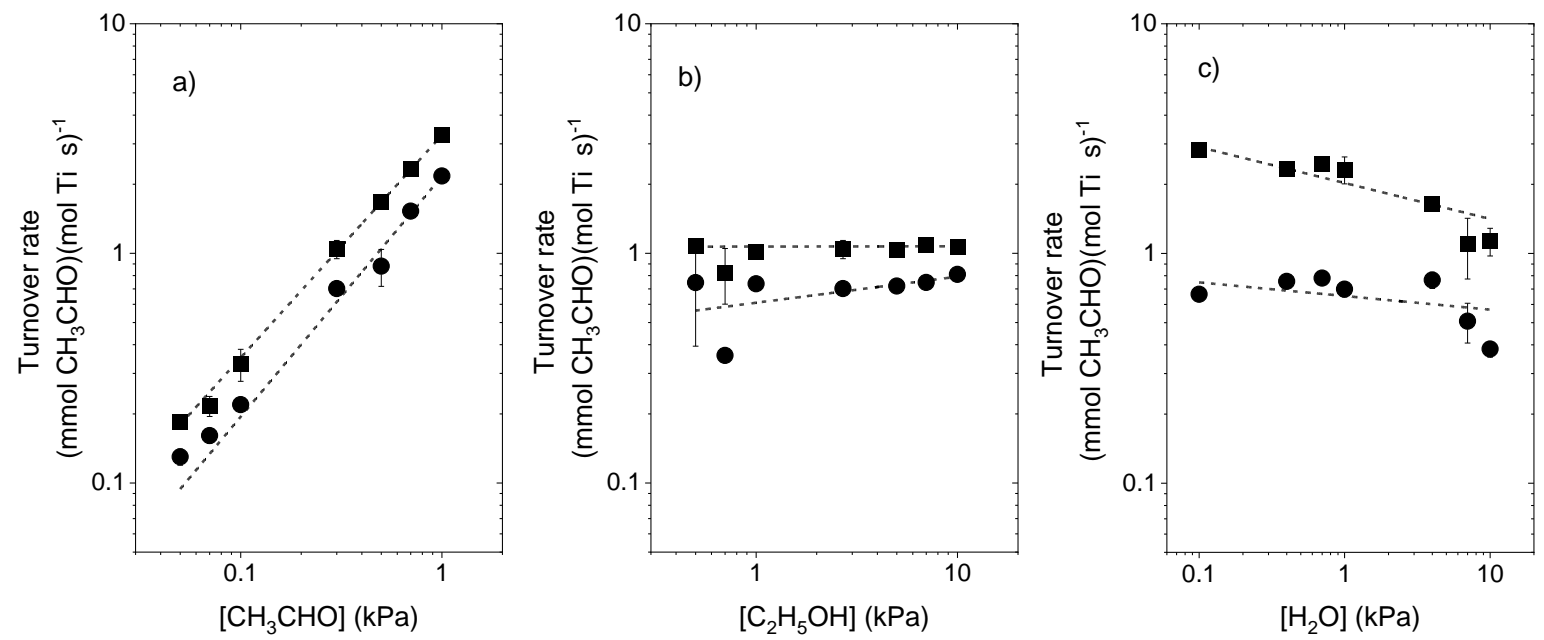

Figure S5. Turnover rate for esterification as functions of the pressure of (a) $\mathrm{CH}_{3} \mathrm{CHO}\left(2.7 \mathrm{kPa} \mathrm{C}_{2} \mathrm{H}_{5} \mathrm{OH}, 15 \mathrm{kPa} \mathrm{H}_{2}\right)$, (b) $\mathrm{C}_{2} \mathrm{H}_{5} \mathrm{OH}\left(0.3 \mathrm{kPa} \mathrm{CH} \mathrm{CHHO}_{3}, 15 \mathrm{kPa} \mathrm{H}_{2}\right)$; and of (c) $\mathrm{H}_{2} \mathrm{O}\left(0.3 \mathrm{kPa} \mathrm{CH} \mathrm{CH}_{3} \mathrm{CHO}, 0.6 \mathrm{kPa} \mathrm{C}_{2} \mathrm{H}_{5} \mathrm{OH}, 15 \mathrm{kPa} \mathrm{H}_{2}\right)$ upon Ti-BEA-75 (ם) and Ti-BEA-250 ( ) catalysts at $503 \mathrm{~K}$. Dashed lines represent fits to functional forms of the rate expressions in Table 1.

Figure $\mathbf{S 4}$ and $\mathbf{S 5}$ show turnover rates for aldol condensation and esterification as functions of partial pressure of $\mathrm{CH}_{3} \mathrm{CHO}, \mathrm{C}_{2} \mathrm{H}_{5} \mathrm{OH}$ and $\mathrm{H}_{2} \mathrm{O}$. The measured power law for Ti-BEA-75 and Ti-BEA-250 are similar to the other TiBEA catalysts. The discussion is shown in main text, section 3.2.1. 


\section{S.2.2. Calculations for Conversion and Selectivity tof Aldol Condensation and Esterification}

Different conversion of acetaldehyde $\left(\mathrm{X}_{\mathrm{CH}_{3} \mathrm{CHO}}\right)$ was achieved at different space velocities. $\mathrm{X}_{\mathrm{CH}_{3} \mathrm{CHO}}$, turnover rate of $\mathrm{CH}_{3} \mathrm{CHO}$ for aldol condensation $\left(r_{\text {aldol }}\right)$ and esterification $\left(r_{\text {ester }}\right)$, selectivity of aldol condensation $\left(S_{\text {aldol }}\right)$ and esterification $\left(S_{\text {ester }}\right)$ are defined by the equations below.

$X_{\mathrm{CH}_{3} \mathrm{CHO}}=\frac{\text { Product formation rates }}{\text { Feeding rate of } \mathrm{CH}_{3} \mathrm{CHO}}$

$r_{\text {aldol }}=\frac{\text { Consumption rate of } \mathrm{CH}_{3} \mathrm{CHO} \text { to aldol condensation }}{\text { mol Ti in the catalyst }}$

$r_{\text {ester }}=\frac{\text { Consumption rate of } \mathrm{CH}_{3} \mathrm{CHO} \text { to esterification }}{\text { mol Ti in the catalyst }}$

$S_{\text {aldol }}=\frac{\text { Consumption rate of } \mathrm{CH}_{3} \mathrm{CHO} \text { to aldol condensation }}{\text { Consumption rate of } \mathrm{CH}_{3} \mathrm{CHO}}$

$S_{\text {ester }}=\frac{\text { Consumption rate of } \mathrm{CH}_{3} \mathrm{CHO} \text { to esterification }}{\text { Consumption rate of } \mathrm{CH}_{3} \mathrm{CHO}}$

Figure S6 shows selectivity versus conversion plots for all Ti-BEA materials. For the reported turnover rates and selectivities in Figure 2, 3, 7a, 8, S4 and S5, conversion was maintained $~ 5 \%$ by adjusting space velocity. 

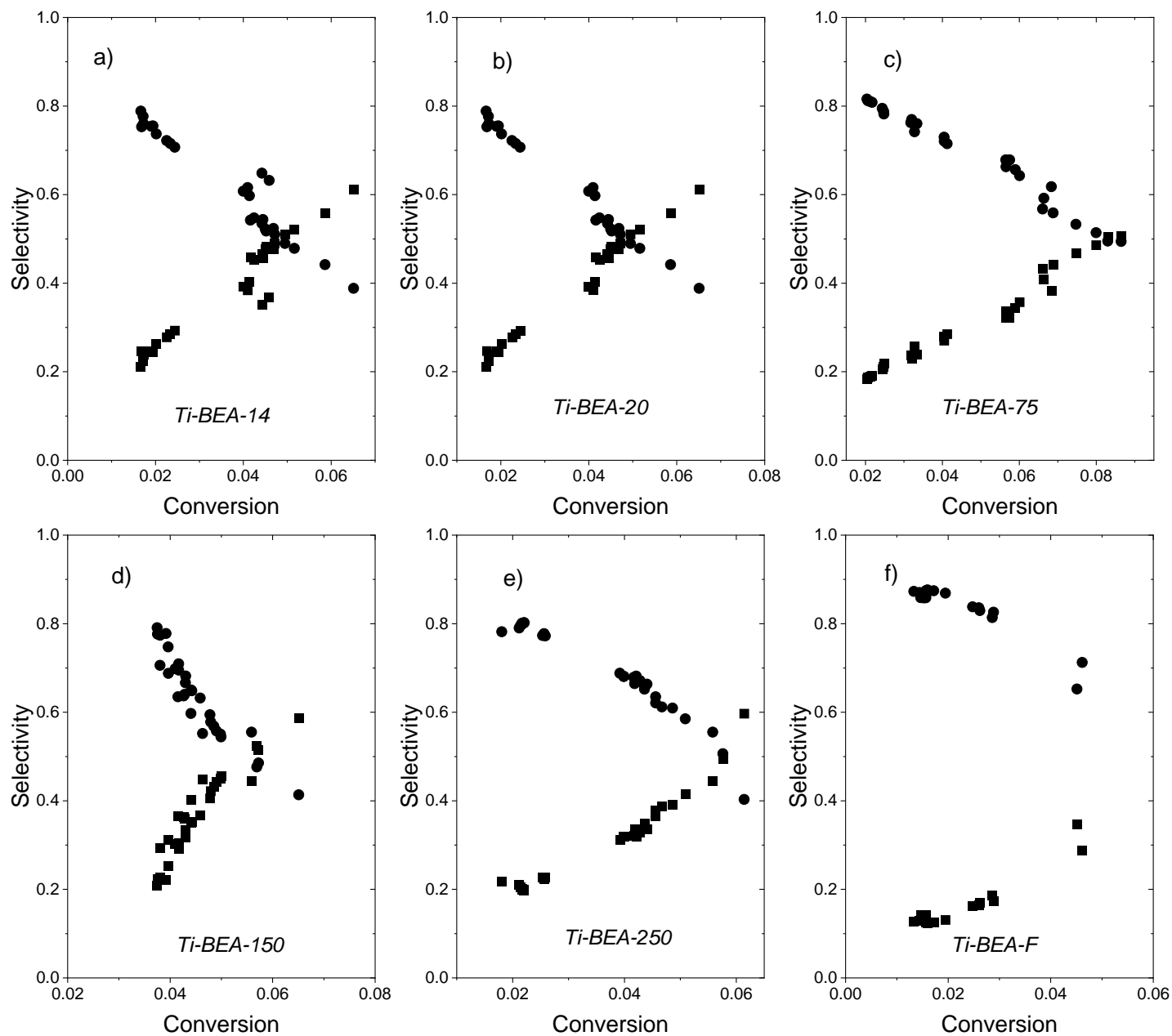

Figure S6. Selectivity versus conversion relationships for aldol-condensation $(\bullet)$ and esterification $(\mathbf{\square})$ for a) TiBEA-14, b) Ti-BEA-20, c) Ti-BEA-75, d) Ti-BEA-150, e) Ti-BEA-250, f) Ti-BEA-F (0.3 kPa $\mathrm{CH}_{3} \mathrm{CHO}, 2.7 \mathrm{kPa}$ $\mathrm{C}_{2} \mathrm{H}_{5} \mathrm{OH}, 15 \mathrm{kPa} \mathrm{H} \mathrm{H}_{2}$ at $\left.503 \mathrm{~K}\right)$. 


\section{S.2.3. Effects of H/D-atom Substitution on Rates of Aldol Condensation and Esterification}

In section 3.2.2, measured kinetic isotope effects are shown when $\mathrm{CD}_{3} \mathrm{CDO}$ or $\mathrm{CD}_{3} \mathrm{CHO}$ replaces $\mathrm{CH}_{3} \mathrm{CHO}$ at certain conditions $\left(0.3 \mathrm{kPa} \mathrm{CH} 3 \mathrm{CHO}_{2}, 2.7 \mathrm{kPa} \mathrm{C}_{2} \mathrm{H}_{5} \mathrm{OH}, 15 \mathrm{kPa} \mathrm{H}_{2}, 503 \mathrm{~K}\right)$. Figure $\mathbf{S 7}$ shows the change in reaction rates of aldol condensation and esterification for all Ti-BEA materials upon isotope substitution, which suggests a normal kinetic isotope effect $\left(k_{e s t e r, H} / k_{e s t e r, D} 1.9-5.6\right)$ for esterification and an inverse or no kinetic isotope effect (i.e., $k_{\text {aldol, } H} / k_{\text {aldol, } D} 0.7-1.0$ ) for aldol condensation.
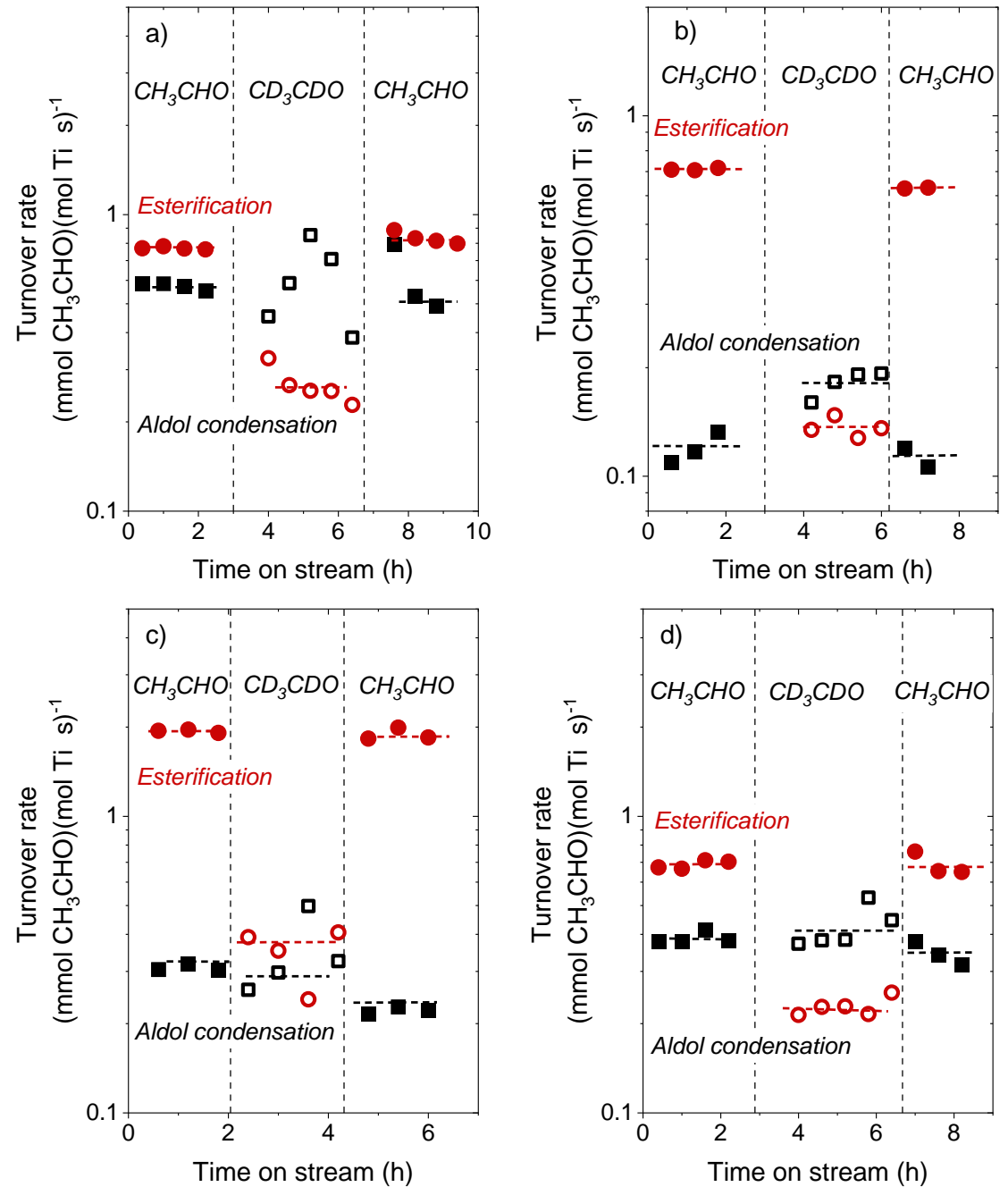

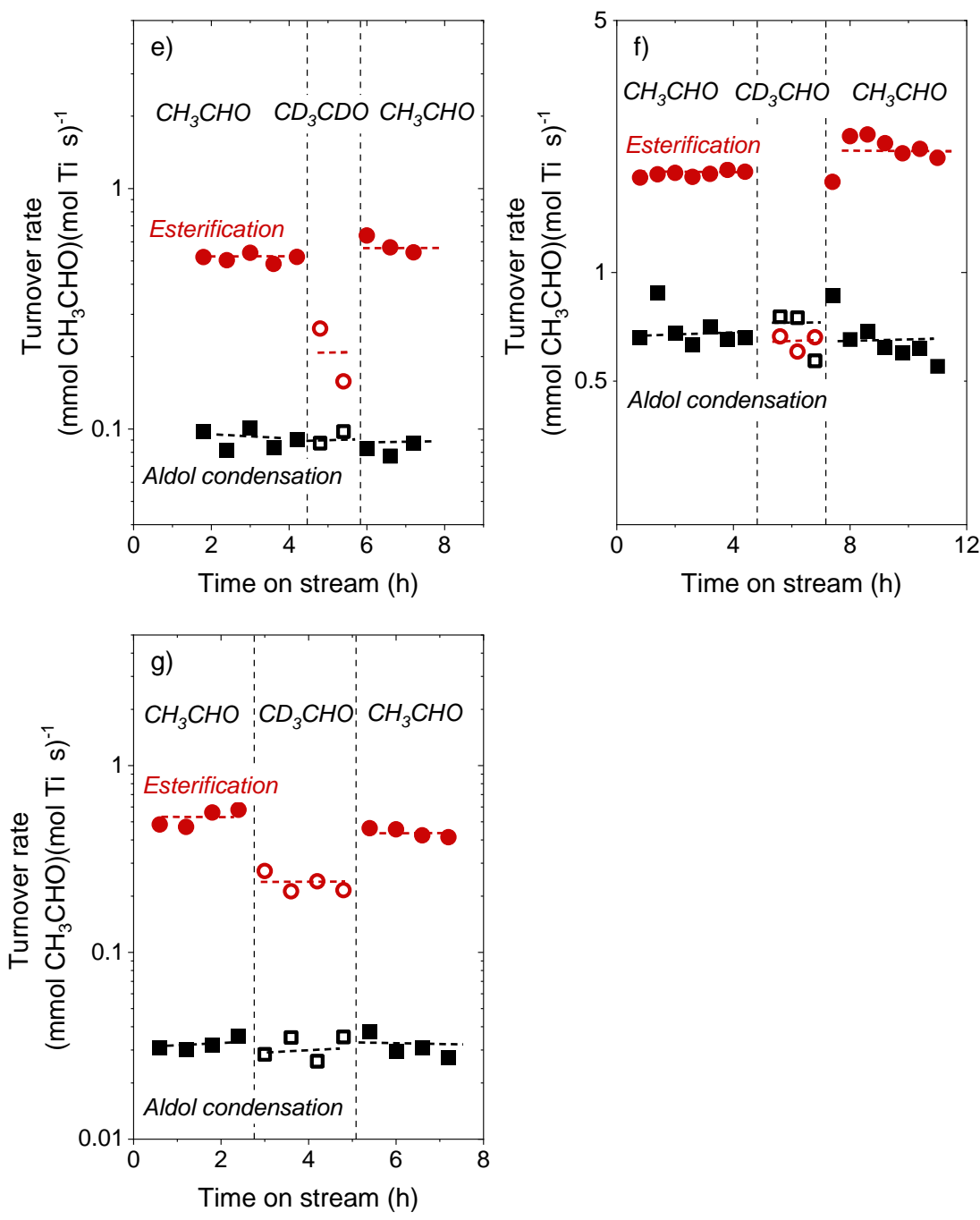

Figure S7. Turnover rate for aldol condensation ( $\square$ ) and esterification ( $\bullet$ by substituting $\mathrm{CH}_{3} \mathrm{CHO}$ (solid symbols) with $\mathrm{CD}_{3} \mathrm{CDO}$ or $\mathrm{CD}_{3} \mathrm{CHO}$ (hollow symbols) for (a) Ti-BEA-14, (b) Ti-BEA-250, (c) Ti-BEA-75, (d) Ti-BEA-150, (e) Ti-BEA-F, (f) Ti-BEA-75 (g) Ti-BEA-F (0.3 kPa CH${ }_{3} \mathrm{CHO}-\mathrm{CD}_{3} \mathrm{CDO}$ or $\mathrm{CD}_{3} \mathrm{CHO}, 2.7 \mathrm{kPa} \mathrm{C}_{2} \mathrm{H}_{5} \mathrm{OH}, 15 \mathrm{kPa} \mathrm{H}_{2}$, $503 \mathrm{~K})$. Dashed lines are used to guide the eye. 


\section{S.2.4 Deactivation Calculation}

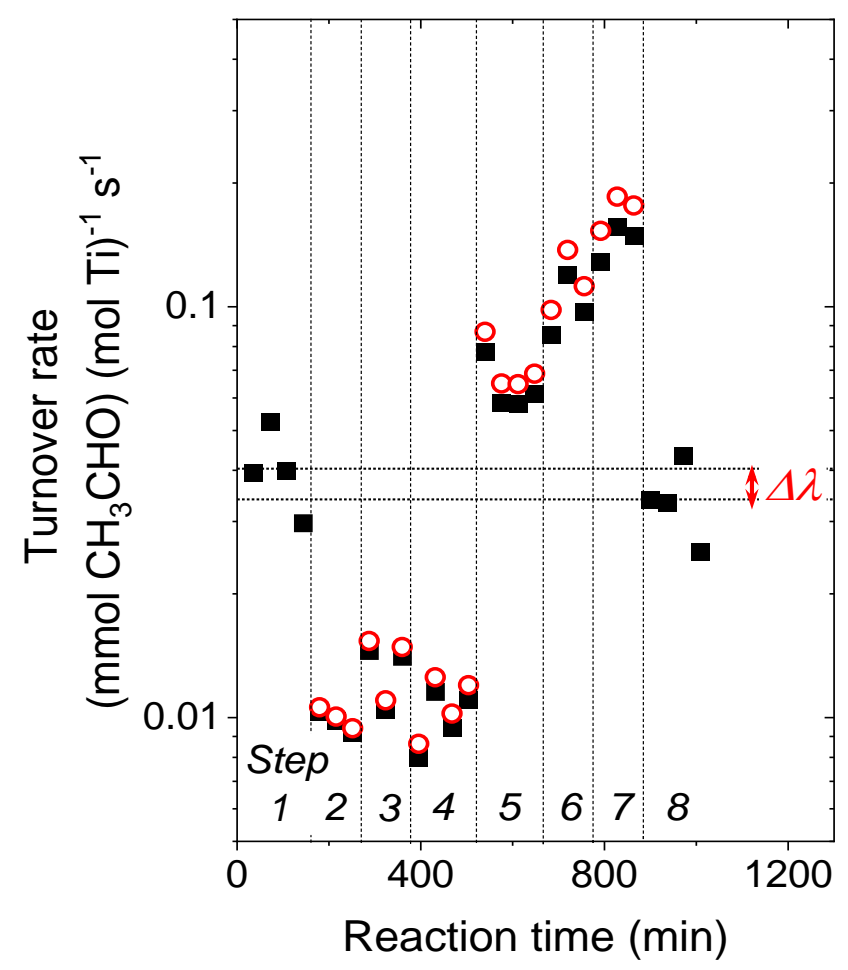

Figure S8. Turnover rate of $\mathrm{CH}_{3} \mathrm{CHO}$ for aldol condensation over Ti-BEA-F as a function of time during a series of experiments in which the pressure of acetaldehyde was changed $(0.05 \mathrm{kPa}-1.0 \mathrm{kPa})$ at constant ethanol and $\mathrm{H}_{2}$ pressures before $(\boldsymbol{\square})$ and after $(\bigcirc)$ deactivation correction $\left(2.7 \mathrm{kPa} \mathrm{C}_{2} \mathrm{H}_{5} \mathrm{OH}, 0.05 \mathrm{kPa}-1.0 \mathrm{kPa} \mathrm{CH}_{3} \mathrm{CHO}, 15 \mathrm{kPa}\right.$ $\left.\mathrm{H}_{2}, 503 \mathrm{~K}\right)$ at differential conversion $(\sim 2 \%)$.

Figure S8 showed measured and corrected turnover rates of $\mathrm{CH}_{3} \mathrm{CHO}$ for aldol condensation over Ti-BEA-F during the measurement of $\mathrm{CH}_{3} \mathrm{CHO}$ pressure dependence. Initial conditions of step 1 were set at $2.7 \mathrm{kPa} \mathrm{C}_{2} \mathrm{H}_{5} \mathrm{OH}, 0.3 \mathrm{kPa}$ $\mathrm{CH}_{3} \mathrm{CHO}, 15 \mathrm{kPa} \mathrm{H}_{2}, 503 \mathrm{~K}$. Pressure of $\mathrm{CH}_{3} \mathrm{CHO}$ was changed to collect rate data under steady state and conditions of step 8 were adjusted as the same as step 1 to determine the extent of deactivation $(\Delta \lambda)$. Turnover rates of $\mathrm{CH}_{3} \mathrm{CHO}$ for aldol addition were corrected using linear interpolation. 


\section{S.3.0. Identifying Reactive Intermediates by In Situ Infrared Spectroscopy}
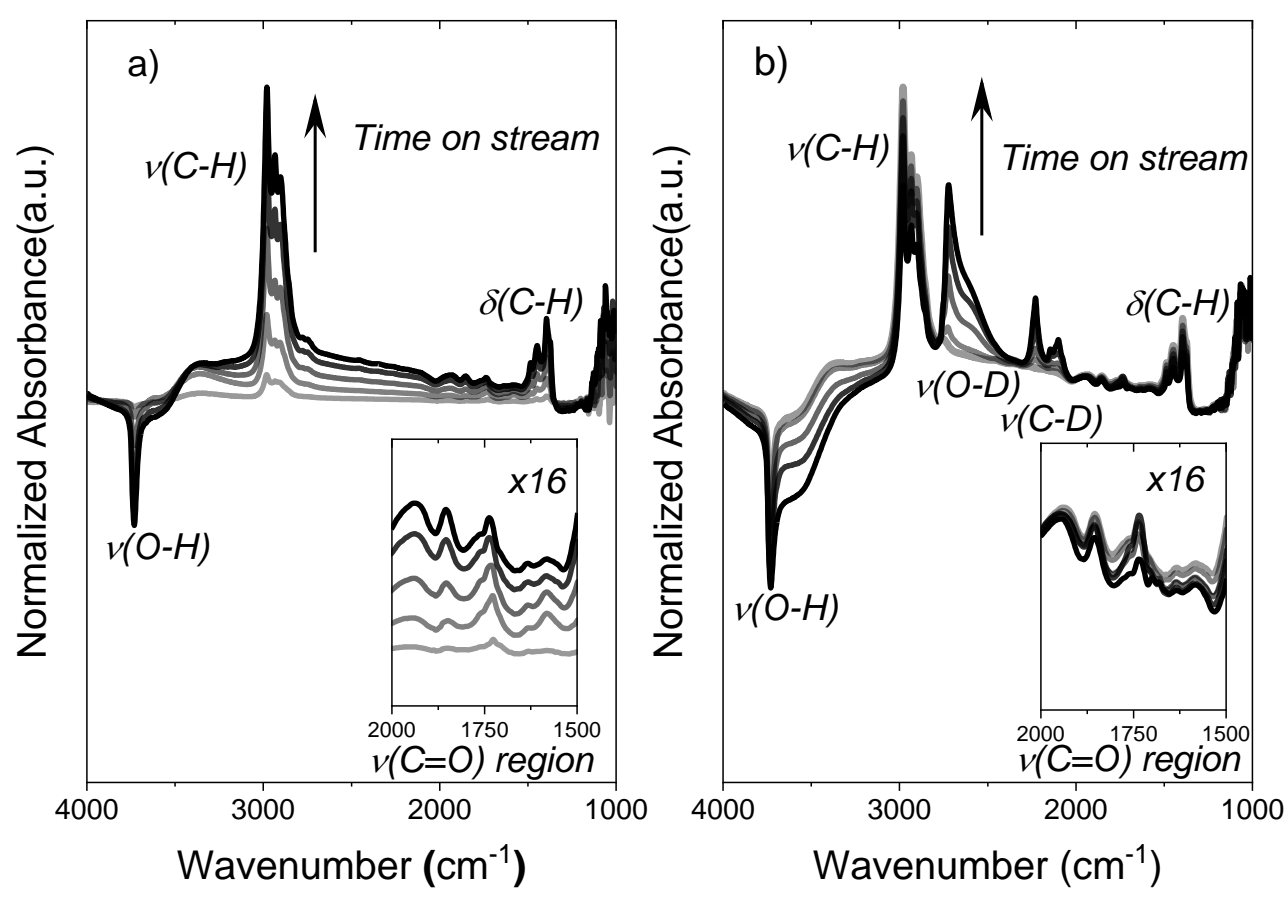

Figure S9. In situ infrared spectra obtained as functions of time over Ti-BEA-F in flowing reactant mixtures (a) during a $19 \mathrm{~h}$ period following initial contact with perhydrogenated reactants $\left(0.3 \mathrm{kPa} \mathrm{CH}_{3} \mathrm{CHO}, 2.6 \mathrm{kPa} \mathrm{C}_{2} \mathrm{H}_{5} \mathrm{OH}, 15 \mathrm{kPa}\right.$ $\mathrm{H}_{2}, 503 \mathrm{~K}$ ), and (b) during subsequent reaction with a mixture of hydrogenated acetaldehyde and perdeuterated ethanol for $4 \mathrm{~h}\left(0.3 \mathrm{kPa} \mathrm{CH}_{3} \mathrm{CHO}, 2.6 \mathrm{kPa} \mathrm{C}_{2} \mathrm{D}_{5} \mathrm{OD}, 15 \mathrm{kPa} \mathrm{H}_{2}, 503 \mathrm{~K}\right)$. Insets show a magnified view of features attributed to $v(\mathrm{C}=\mathrm{O})$ modes of adsorbed $\mathrm{CH}_{3} \mathrm{CHO}$. All spectra are normalized to the $v(\mathrm{Si}-\mathrm{O}-\mathrm{Si})$ overtone at $1876 \mathrm{~cm}^{-1}$ of the dehydrated catalyst prior to reaction, which provides a consistent basis for comparison as a function of time and between spectra obtained on distinct samples. The background for each spectrum was obtained for a fresh sample at $503 \mathrm{~K}$ following pretreatment $\left(15 \mathrm{kPa} \mathrm{H}_{2}, 86 \mathrm{kPa} \mathrm{He}, 553 \mathrm{~K}, 2 \mathrm{~h}\right)$. 

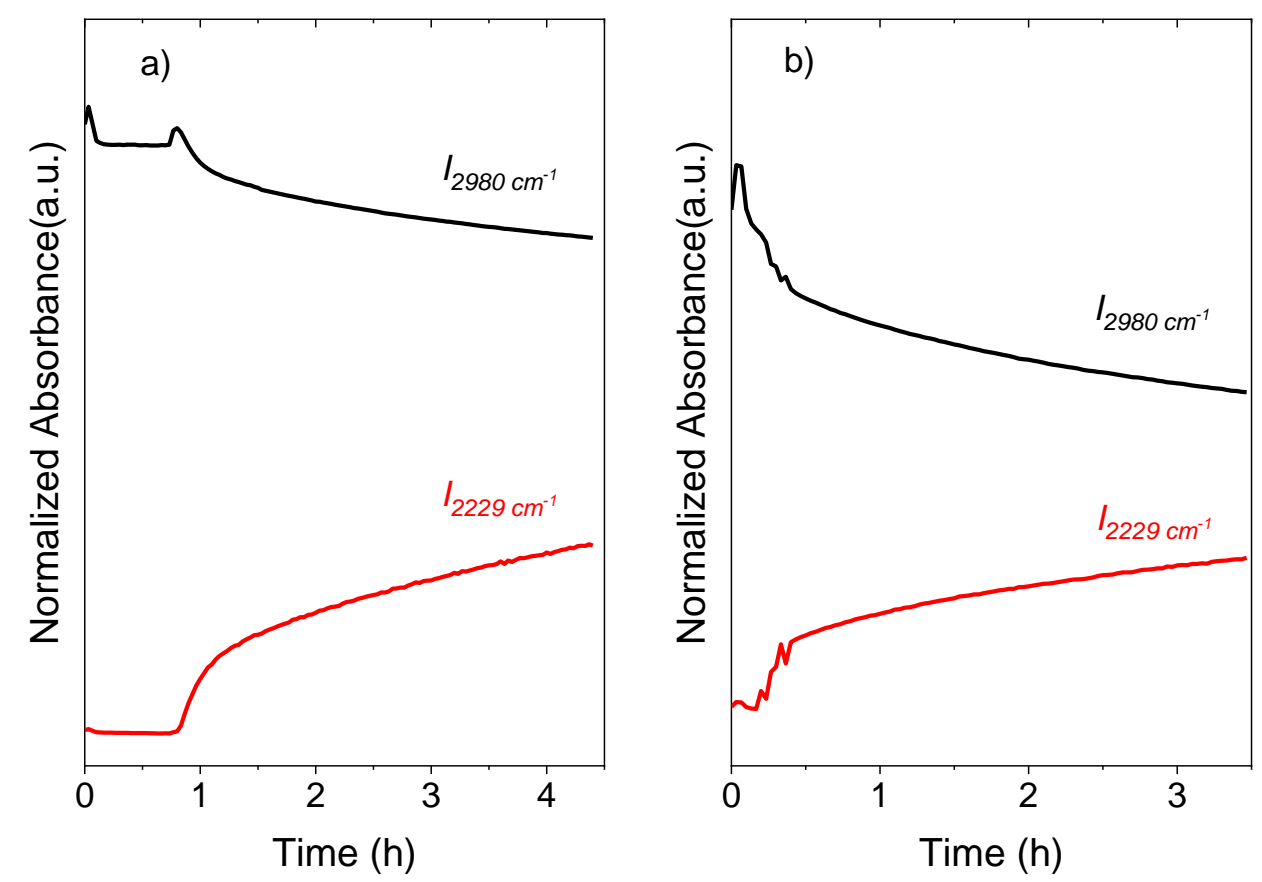

Figure S10. Normalized absorbance intensities of the features at $(-) 2980 \mathrm{~cm}^{-1}\left(\mathrm{~V}_{\mathrm{as}}\left(\mathrm{CH}_{3}\right)\right)$ and $(-) 2229 \mathrm{~cm}^{-1}$ $\left(\mathrm{V}_{\mathrm{as}}\left(\mathrm{CD}_{3}\right)\right)$ as a function of time after switching to a mixture of hydrogenated acetaldehyde and perdeuterated ethanol (0.3 kPa CH $3 \mathrm{CHO}_{3} 2.6 \mathrm{kPa} \mathrm{C} \mathrm{D}_{5} \mathrm{OD}, 15 \mathrm{kPa} \mathrm{H}_{2}, 503 \mathrm{~K}$ ) over (a) Ti-BEA-14 and (b) Ti-BEA-F. The initial experimental time $(\mathrm{t}=0)$ corresponds to a period at which the spectra of species had ceased changing (implying steady state conditions hold) during contact with hydrogenated reactants $\left(0.3 \mathrm{kPa} \mathrm{CH}_{3} \mathrm{CHO}, 2.6 \mathrm{kPa} \mathrm{C}_{2} \mathrm{H}_{5} \mathrm{OH}, 15 \mathrm{kPa} \mathrm{H}\right.$, $503 \mathrm{~K})$. 
S.4.0. Derivation of the Rate Expression for Aldol Condensation and Esterification

S.4.1. Elementary Steps for Aldol Condensation and Esterification on Ti-BEA

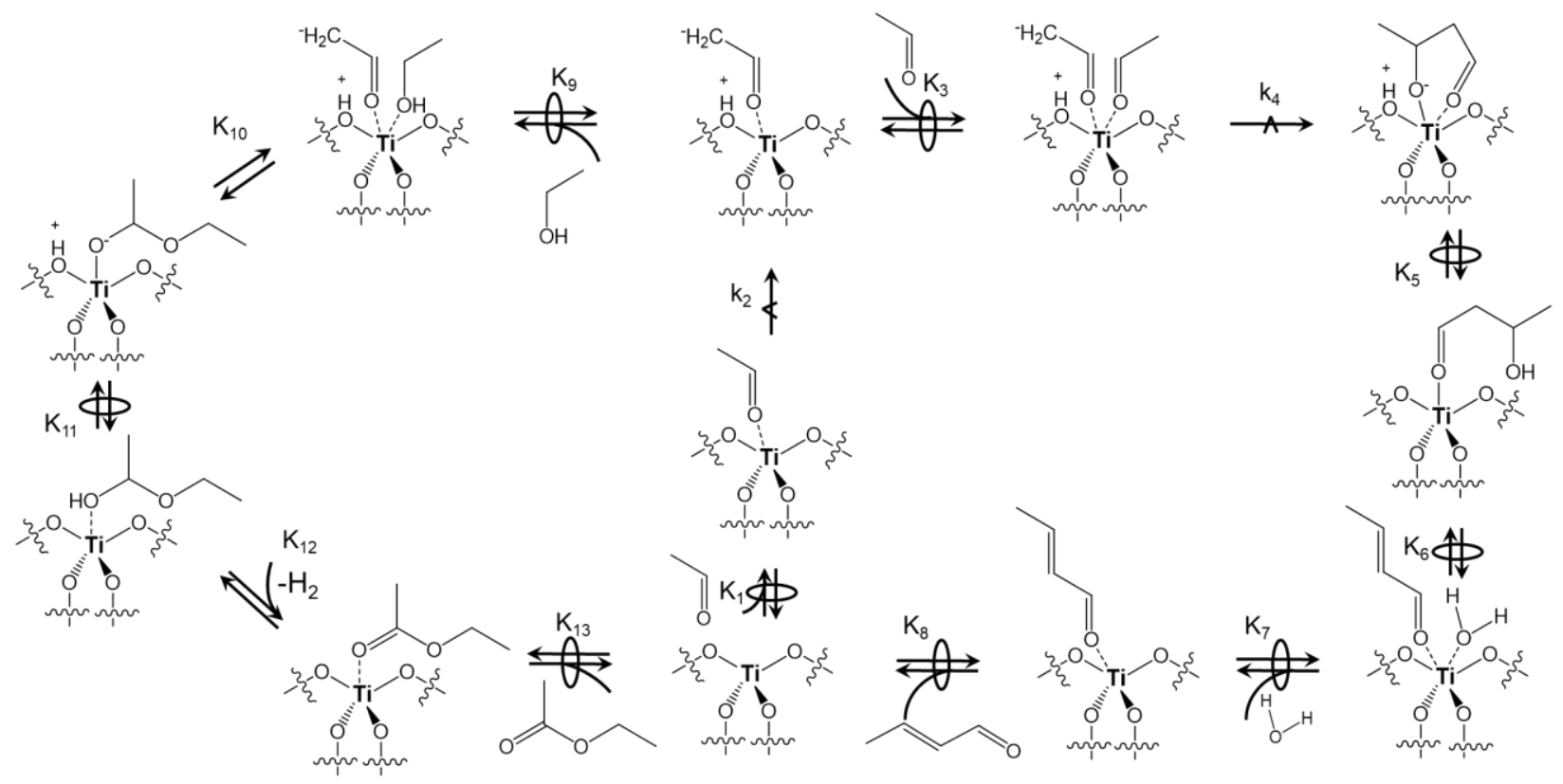

Scheme S1. Proposed elementary steps for aldol condensation and esterification on Ti-BEA; Symbol $\oiiint$ represents a quasi-equilibrated step, and $\longrightarrow$ represents a kinetically relevant step. $K_{i}$ is the equilibrium constant for step $i$, and $\mathrm{k}_{\mathrm{i}}$ is the rate constant of step $\mathrm{i}$.

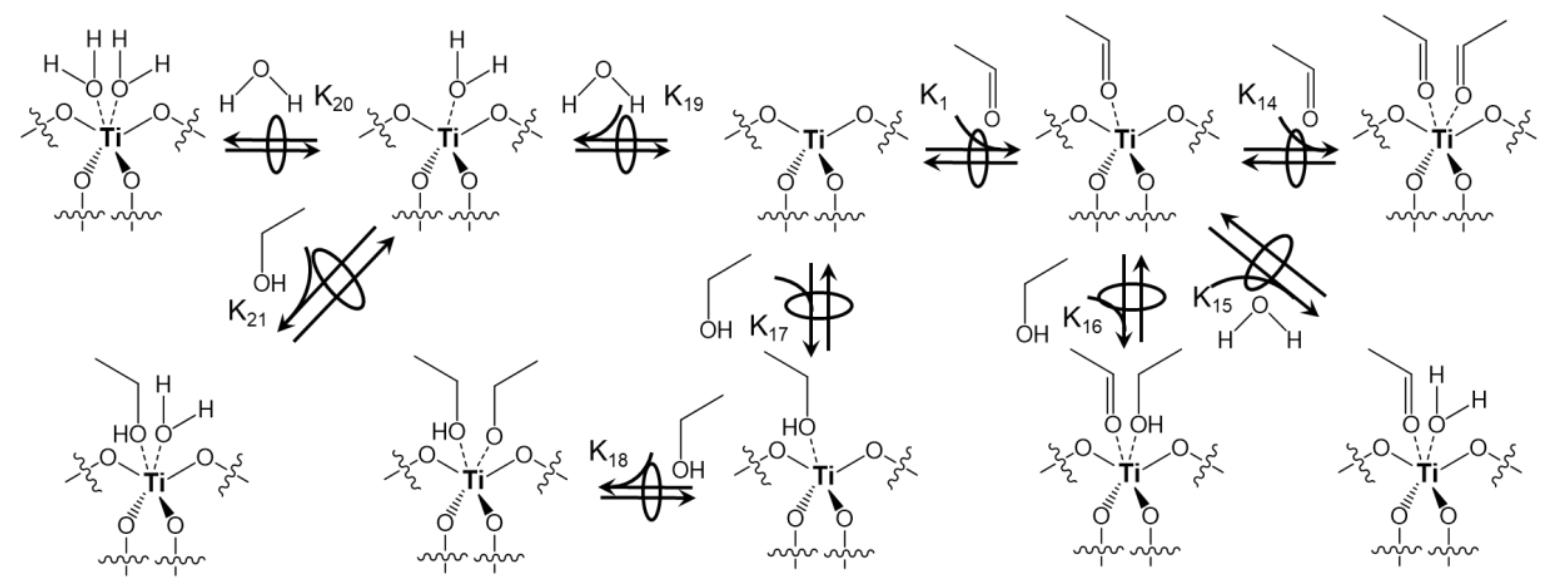

Scheme S2. Proposed elementary steps for competitive adsorption of $\mathrm{CH}_{3} \mathrm{CHO}, \mathrm{C}_{2} \mathrm{H}_{5} \mathrm{OH}$ and $\mathrm{H}_{2} \mathrm{O}$ on Ti-BEA; Symbol $\oiiint$ represents a quasi-equilibrated step, and $\rightarrow$ represents a kinetically relevant step. $K_{i}$ is the equilibrium constant for step $\mathrm{i}$, and $\mathrm{k}_{\mathrm{i}}$ is the rate constant of step $\mathrm{i}$. 
Aldol condensation:

$$
\begin{aligned}
& \mathrm{CH}_{3} \mathrm{CHO}+*_{\mathrm{Ti}} \quad \mathrm{CH}_{3} \mathrm{CHO} *_{T i} \\
& \left(\mathrm{CH}_{3} \mathrm{CHO}\right) *_{\mathrm{Ti}}+*_{\mathrm{O}} \quad \rightarrow \quad\left(\mathrm{CH}_{2} \mathrm{CHO}\right) *_{\mathrm{Ti}}+\mathrm{H} *_{\mathrm{O}} \\
& \left.\mathrm{CH}_{3} \mathrm{CHO}+\left(\mathrm{CH}_{2} \mathrm{CHO}\right) *_{\mathrm{Ti}} \quad \text { 政 } \mathrm{CHO}\right)\left(\mathrm{CH}_{2} \mathrm{CHO}\right) * \mathrm{Ti} \\
& \left(\mathrm{CH}_{3} \mathrm{CHO}\right)\left(\mathrm{CH}_{2} \mathrm{CHO}\right) * *_{\mathrm{Ti}} \quad \longrightarrow \quad\left(\mathrm{C}_{4} \mathrm{H}_{7} \mathrm{O}_{2}\right) * \mathrm{Ti} \\
& \left(\mathrm{C}_{4} \mathrm{H}_{7} \mathrm{O}_{2}\right) *_{T i}+\mathrm{H} *_{O} \quad \rightleftarrows \quad\left(\mathrm{C}_{4} \mathrm{H}_{8} \mathrm{O}_{2}\right) *_{T i}+*_{O} \\
& \left(\mathrm{C}_{4} \mathrm{H}_{8} \mathrm{O}_{2}\right) *_{T i} \quad\left(\mathrm{H}_{2} \mathrm{O}\right)\left(\mathrm{C}_{4} \mathrm{H}_{6} \mathrm{O}\right) *_{T i} \\
& \left(\mathrm{H}_{2} \mathrm{O}\right)\left(\mathrm{C}_{4} \mathrm{H}_{6} \mathrm{O}\right) *_{T i} \quad \mathrm{H}_{2} \mathrm{O}+\left(\mathrm{C}_{4} \mathrm{H}_{6} \mathrm{O}\right) *_{T i} \\
& \left(\mathrm{C}_{4} \mathrm{H}_{6} \mathrm{O}\right) *_{T i} \quad \mathrm{C}_{4} \mathrm{H}_{6} \mathrm{O}+*_{T i} \\
& \left(\mathrm{CH}_{2} \mathrm{CHO}\right) *_{T i}+\mathrm{C}_{2} \mathrm{H}_{5} \mathrm{OH} \\
& \oiiint \quad\left(\mathrm{C}_{2} \mathrm{H}_{5} \mathrm{OH}\right)\left(\mathrm{CH}_{2} \mathrm{CHO}\right) *_{T i} \\
& \left(\mathrm{C}_{2} \mathrm{H}_{5} \mathrm{OH}\right)\left(\mathrm{CH}_{2} \mathrm{CHO}\right) *_{T i} \\
& \rightleftarrows \\
& \left(\mathrm{C}_{4} \mathrm{H}_{9} \mathrm{O}_{2}\right) *_{T i} \\
& \left(\mathrm{C}_{4} \mathrm{H}_{10} \mathrm{O}_{2}\right) * T i \\
& \left(\mathrm{C}_{4} \mathrm{H}_{10} \mathrm{O}_{2}\right) *_{T i} \\
& \left(\mathrm{C}_{4} \mathrm{H}_{8} \mathrm{O}_{2}\right) *_{T i} \\
& \text { f } \\
& \left(\mathrm{C}_{4} \mathrm{H}_{8} \mathrm{O}_{2}\right) *_{T i}+\mathrm{H}_{2} \\
& \mathrm{C}_{4} \mathrm{H}_{8} \mathrm{O}_{2}+{ }^{*} \mathrm{Ti}
\end{aligned}
$$

Esterification:

Competitive adsorption:

$$
\begin{gathered}
\left(\mathrm{CH}_{3} \mathrm{CHO}\right) *_{\mathrm{Ti}}+\mathrm{CH}_{3} \mathrm{CHO} \\
\left(\mathrm{CH}_{3} \mathrm{CHO}\right) *_{\mathrm{Ti}}+\mathrm{H}_{2} \mathrm{O} \\
\left(\mathrm{CH}_{3} \mathrm{CHO}\right) *_{\mathrm{Ti}}+\mathrm{C}_{2} \mathrm{H}_{5} \mathrm{OH} \\
\mathrm{C}_{2} \mathrm{H}_{5} \mathrm{OH}+*_{\mathrm{Ti}} \\
\left(\mathrm{C}_{2} \mathrm{H}_{5} \mathrm{OH}\right) *_{\mathrm{Ti}}+\mathrm{C}_{2} \mathrm{H}_{5} \mathrm{OH} \\
\mathrm{H}_{2} \mathrm{O}+*_{\mathrm{Ti}} \\
\mathrm{H}_{2} \mathrm{O}+\left(\mathrm{H}_{2} \mathrm{O}\right) *_{\mathrm{Ti}} \\
\mathrm{C}_{2} \mathrm{H}_{5} \mathrm{OH}+\left(\mathrm{H}_{2} \mathrm{O}\right) *_{\mathrm{Ti}}
\end{gathered}
$$

In section 3.2.2 and S 2.4, we have shown changes in reaction rates of aldol condensation and esterification upon isotope substitution. It can be concluded that enolate formation (step 2) is the kinetically relevant step for esterification because a normal kinetic isotope effect $\left(k_{e s t e r, H} / k_{\text {ester, } D} \sim 1.9-5.6\right)$ is confirmed. For aldol condensation, measured $k_{\text {aldol,H}} / k_{\text {aldol, } D}$ ranges between 0.7 and 1 , which is smaller than a generally reported normal kinetic isotope effect (e.g., $\left.k_{H} / k_{D} \sim 2.3\right)^{8}$ and the normal kinetic isotope effect $\left(k_{e s t e r, H} / k_{e s t e r, D} 1.9-5.6\right)$ in this work for esterification, a safe interpretation is that $\mathrm{C}-\mathrm{H}$ bond cleavage or formation (i.e., step 2, 5 and 6 corresponding to deprotonation of $\left(\mathrm{CH}_{3} \mathrm{CHO}\right) *_{\mathrm{Ti}}$, protonation of $\left(\mathrm{C}_{4} \mathrm{H}_{7} \mathrm{O}_{2}\right) *_{\mathrm{Ti}}$ and dehydration of $\left.\left(\mathrm{C}_{4} \mathrm{H}_{8} \mathrm{O}_{2}\right) *_{\mathrm{Ti}}\right)$ is not involved in the kinetically relevant steps. 
Scheme S1 shows aldol condensation and esterification are parallel reactions and both consume enolate species formed by deprotonation of $\mathrm{CH}_{3} \mathrm{CHO}$. Enolate formation rate (i.e., $r_{\text {enolate }}$ ) should equal the sum of aldol condensation rate (i.e., $r_{\text {aldol }}$ ), and esterification rate (i.e., $r_{\text {ester }}$ ), which can be expressed as follows:

$$
\begin{aligned}
& r_{\text {enolate }}=k_{2} K_{1}\left[\mathrm{CH}_{3} \mathrm{CHO}\right]\left[*_{T i}\right]\left[*_{O}\right] \\
& r_{\text {enolate }}=r_{\text {ester }}+r_{\text {aldol }}
\end{aligned}
$$

where $k_{2}$ is the rate constant of step 2 , and $\left[{ }_{T i}\right]\left[*_{O}\right]$ represent unoccupied Ti and $\mathrm{O}$ sites. In the following sections, detailed derivations for different possible kinetically relevant steps and MARI assumptions are shown as supplements to the discussion in the main content.

\section{S.4.2. Complete Derivation of the Rate Expressions for Aldol Condensation and Esterification Reactions}

Rate expressions for aldol condensation and esterification can be derived for the sequence of steps that involve kinetically relevant and irreversible enolate formation, which is followed by nucleophilic attack to form the aldol and hemiacetal to yield the ester.

When nucleophilic attack of enolate to acetaldehyde (step 4) is the kinetically relevant step for aldol condensation, $r_{\text {aldol }}$ can be expressed as:

$r_{\text {aldol }}=k_{4}\left[\left(\mathrm{C}_{2} \mathrm{H}_{3} \mathrm{O}\right) *_{T i}\right] K_{3}\left[\mathrm{CH}_{3} \mathrm{CHO}\right]$

where $k_{4}$ is the rate constant of step $4,\left[\left(\mathrm{C}_{2} \mathrm{H}_{3} \mathrm{O}\right) *_{T i}\right]$ is the coverage of enolate species on Ti sites. During the reaction processes, it can be assumed net rate of change of the coverage of enolate species is zero (i.e., pseudo steady-state hypothesis (PSSH) for enolate species), which gives:

$$
\begin{gathered}
\frac{d_{\left[\left(C_{2} \mathrm{H}_{3} O\right) *_{T i}\right]} d_{t}}{d_{t}} k_{2} K_{1}\left[\mathrm{CH}_{3} \mathrm{CHO}\right]\left[*_{T i}\right]\left[*_{O}\right]-k_{-2}\left[\left(\mathrm{C}_{2} \mathrm{H}_{3} \mathrm{O}\right) *_{T i}\right]\left[\mathrm{H}_{O}^{*}\right]-k_{4} K_{3}\left[\mathrm{CH}_{3} \mathrm{CHO}\right]\left[\left(\mathrm{C}_{2} \mathrm{H}_{3} \mathrm{O}\right) *_{T i}\right] \\
-k_{10} K_{9}\left[\mathrm{C}_{2} \mathrm{H}_{5} \mathrm{OH}\right]\left[\left(\mathrm{C}_{2} \mathrm{H}_{3} \mathrm{O}\right) *_{T i}\right]+k_{-10}\left[\left(\mathrm{C}_{4} \mathrm{H}_{9} \mathrm{O}_{2}\right) *_{T i}\right]=0
\end{gathered}
$$

It can be assumed $r_{2} \gg r_{-2}$ (i.e., enolate formation is not reversible), because enolate formation is kinetically relevant for esterification. In addition, values of $\left[\left(\mathrm{C}_{4} \mathrm{H}_{9} \mathrm{O}_{2}\right) *_{T i}\right]$ are assumed to be negligible since reactions are operated at differential conversions and pressure of reactants (e.g., $\mathrm{CH}_{3} \mathrm{CHO}$ and $\mathrm{C}_{2} \mathrm{H}_{5} \mathrm{OH}$ ) are 100 times larger than that of ethyl acetate product. Based on these assumptions and equation $\mathrm{S} 4-4$, enolate coverage (i.e., $\left.\left[\left(\mathrm{C}_{2} \mathrm{H}_{3} \mathrm{O}\right) *_{T i}\right]\right)$ are assumed to be:

$$
\left[\left(\mathrm{C}_{2} \mathrm{H}_{3} \mathrm{O}\right) *_{T i}\right]=\frac{k_{2} \mathrm{~K}_{1}\left[\mathrm{CH}_{3} \mathrm{CHO}\right]\left[*_{T i}\right]\left[*_{o}\right]}{k_{4} K_{3}\left[\mathrm{CH}_{3} \mathrm{CHO}\right]+k_{10} \mathrm{~K}_{9}\left[\mathrm{C}_{2} \mathrm{H}_{5} \mathrm{OH}\right]}
$$

Combining equations S4-1 to S4-5, rates of aldol condensation and esterification can be further expressed as:

$$
r_{\text {aldol }}=\frac{k_{4} K_{3} k_{2} K_{1}\left[\mathrm{CH}_{3} \mathrm{CHO}\right]^{2}\left[*_{T i}\right]\left[*_{o}\right]}{k_{4} K_{3}\left[\mathrm{CH}_{3} \mathrm{CHO}\right]+k_{10} K_{9}\left[C_{2} \mathrm{H}_{5} \mathrm{OH}\right]}
$$


$r_{\text {ester }}=\frac{k_{10} K_{9}\left[\mathrm{C}_{2} \mathrm{H}_{5} \mathrm{OH}\right] k_{2} K_{1}\left[\mathrm{CH}_{3} \mathrm{CHO}\right]\left[*_{T i}\right]\left[*_{O}\right]}{k_{4} K_{3}\left[\mathrm{CH}_{3} \mathrm{CHO}\right]+k_{10} K_{9}\left[\mathrm{C}_{2} \mathrm{H}_{5} \mathrm{OH}\right]}$

Equation S4-6 and S4-7 suggest $r_{a l d o l}$ and $r_{e s t e r}$ are influenced by $\left[*_{T i}\right]\left[*_{O}\right]$ that is affected by MARI. Since it is hard to confirm the most abundant reactive intermediate through infrared spectroscopy, we attempt to assume different species (e.g., empty sites, $\mathrm{C}_{2} \mathrm{H}_{5} \mathrm{OH}$ derived species, and $\mathrm{CH}_{3} \mathrm{CHO}$ derived species) as MARI and compare the simplified rate expression with measured pressure dependences. Here, esterification is used as an example because measured pressure dependencies $\left(r_{e s t e r}=k_{a p p}\left[\mathrm{C}_{2} \mathrm{H}_{4} \mathrm{O}\right]^{1}\left[\mathrm{C}_{2} \mathrm{H}_{5} \mathrm{OH}\right]^{0}\right)$ are very similar on all catalysts. At reaction conditions, $\mathrm{Ti}$ and $\mathrm{O}$ sites can be occupied by possible species, which gives:

$$
\begin{aligned}
& {\left[L *_{T i}\right]=\left[*_{T i}\right]+\left[\left(\mathrm{CH}_{3} \mathrm{CHO}\right) *_{T i}\right]+\left[\left(\mathrm{C}_{2} \mathrm{H}_{5} \mathrm{OH}\right) *_{T i}\right]+\left[\left(\mathrm{CH}_{2} \mathrm{CHO}\right) *_{T i}\right]+\left[\left(\mathrm{C}_{4} \text { species }\right) *_{T i}\right]} \\
& {\left[L *_{O}\right]=\left[*_{O}\right]+\left[\mathrm{H} *_{O}\right]}
\end{aligned}
$$

Here, it can be assumed MARI on $\mathrm{O}$ site is $*_{O}$ (i.e., unoccupied), because one Ti site corresponds to four $\mathrm{O}$ sites that presumably remain empty at reaction conditions. For Ti sites, coverages of $\mathrm{C}_{4}$ intermediates are negligible based on the fact that concentrations of $\mathrm{C}_{2}$ species are orders of magnitude larger than $\mathrm{C}_{4}$ species at differential conversions.

Table $\mathbf{S 2}$ shows the simplified rate expressions for esterification and compares those to measured power law $\left(r_{\text {ester }}=k_{\text {app }}\left[\mathrm{C}_{2} \mathrm{H}_{4} \mathrm{O}\right]^{1}\left[\mathrm{C}_{2} \mathrm{H}_{5} \mathrm{OH}\right]^{0}\right)$. The only combination of assumptions that appear consistent with measured rates are to assume that empty sites are the MARI (i.e., $\left[L *_{T i}\right]=\left[*_{T i}\right] ;\left[L *_{0}\right]=\left[*_{O}\right]$ ). The other assumptions fail, because the simplified rate expression cannot satisfy the apparent power laws measured for esterification.

Table S2. MARI assumptions on Ti sites and corresponding rate expressions

\begin{tabular}{|c|c|}
\hline MARI assumption & $\frac{r_{\text {ester }}}{\left.\left[\mathrm{L}_{T i} \mathrm{~T}\right] \mathrm{L} *_{\mathrm{O}}\right]}=$ \\
\hline$\left(\mathrm{C}_{2} \mathrm{H}_{5} \mathrm{OH}\right) *_{T i}$ & $\frac{k_{10} k_{2} \mathrm{~K}_{1}\left[\mathrm{CH}_{3} \mathrm{CHO}\right]}{k_{4} K_{3}\left[\mathrm{CH}_{3} \mathrm{CHO}\right]+k_{10} \mathrm{~K}_{9}\left[\mathrm{C}_{2} \mathrm{H}_{5} \mathrm{OH}\right]}$ \\
\hline$\left(\mathrm{CH}_{2} \mathrm{CHO}\right) *_{T i}$ & $k_{10} \mathrm{~K}_{9}\left[\mathrm{C}_{2} \mathrm{H}_{5} \mathrm{OH}\right]$ \\
\hline$\left(\mathrm{CH}_{3} \mathrm{CHO}\right) *_{\mathrm{Ti}}$ & $\frac{k_{2} k_{10} \mathrm{~K}_{9}\left[\mathrm{C}_{2} \mathrm{H}_{5} \mathrm{OH}\right]}{k_{4} K_{3}\left[\mathrm{CH}_{3} \mathrm{CHO}\right]+k_{10} \mathrm{~K}_{9}\left[\mathrm{C}_{2} \mathrm{H}_{5} \mathrm{OH}\right]}$ \\
\hline Empty sites & $\frac{k_{10} \mathrm{~K}_{9}\left[\mathrm{C}_{2} \mathrm{H}_{5} \mathrm{OH}\right] k_{2} \mathrm{~K}_{1}\left[\mathrm{CH}_{3} \mathrm{CHO}\right]}{k_{4} K_{3}\left[\mathrm{CH}_{3} \mathrm{CHO}\right]+k_{10} \mathrm{~K}_{9}\left[\mathrm{C}_{2} \mathrm{H}_{5} \mathrm{OH}\right]}$ \\
\hline
\end{tabular}

On Ti-BEA catalysts, Ti sites serve as Lewis acid center and the adjacent $\mathrm{O}$ atoms act as basic sites, which always find each other since Ti atoms are well-dispersed in zeolite frameworks. Thus, $\left[{ }^{*} T\right]\left[*_{O}\right]$ can be revised as $\left[*_{T i-O}\right]$ that represents Lewis acid base pairs. Rate expressions of aldol condensation and esterification (equation S4-6 and S4-7) can be further expressed into:

$$
\frac{r_{\text {aldol }}}{\left[L *_{\text {Ti-O }}\right]}=\frac{k_{4} K_{3} k_{2} K_{1}\left[\mathrm{CH}_{3} \mathrm{CHO}\right]^{2}}{k_{4} \mathrm{~K}_{3}\left[\mathrm{CH}_{3} \mathrm{CHO}\right]+k_{10} \mathrm{~K}_{9}\left[\mathrm{C}_{2} \mathrm{H}_{5} \mathrm{OH}\right]}
$$


$\frac{r_{\text {ester }}}{\left[*_{\text {Ti-O }}\right]}=\frac{k_{10} \mathrm{~K}_{9}\left[\mathrm{C}_{2} \mathrm{H}_{5} \mathrm{OH}\right] k_{2} \mathrm{~K}_{1}\left[\mathrm{CH}_{3} \mathrm{CHO}\right]}{k_{4} \mathrm{~K}_{3}\left[\mathrm{CH}_{3} \mathrm{CHO}\right]+k_{10} K_{9}\left[\mathrm{C}_{2} \mathrm{H}_{5} \mathrm{OH}\right]}$

in which $\left[L *_{T i-O}\right]$ is the number of total Ti-O sites. To explain the measured rate data by these rate expressions, equation S4-10 and S4-11 are linearized as functions of partial pressure ratio of $\mathrm{C}_{2} \mathrm{H}_{5} \mathrm{OH}$ and $\mathrm{CH}_{3} \mathrm{CHO}$, which gives:

$$
\begin{aligned}
& \frac{\left[\mathrm{CH}_{3} \mathrm{CHO}\right]}{\frac{r_{\text {aldol }}}{\left[{ }^{*}{ }_{\text {Ti-O }}\right]}}=\frac{1}{k_{4} K_{3}}+\frac{k_{10} K_{9}\left[\mathrm{C}_{2} \mathrm{H}_{5} \mathrm{OH}\right]}{k_{4} K_{1} K_{2} K_{3}\left[\mathrm{CH}_{3} \mathrm{CHO}\right]} \\
& \frac{\left[\mathrm{C}_{2} \mathrm{H}_{5} \mathrm{OH}\right]}{\frac{r_{\text {ester }}}{\left[L *_{\text {Ti-o }}\right]}}=\frac{k_{4} K_{3}}{k_{10} K_{9} k_{2} K_{1}}+\frac{\left[\mathrm{C}_{2} \mathrm{H}_{5} \mathrm{OH}\right]}{k_{2} K_{1}\left[\mathrm{CH}_{3} \mathrm{CHO}\right]}
\end{aligned}
$$

Figure 6 in the main text shows the fitting of Ti-BEA-150, and Figure S11 here show the fitting for other Ti-BEA catalysts of equation S4-12 and S4-13. Within error bars, the fits suggest measured rate data can be explained by the kinetic model described (other proposals given in following sections result in poorer quality fits). The quality of these fits, together with measured kinetic isotope effects, imply that aldol condensation and esterification reactions occur on predominately unoccupied $\mathrm{Ti}$ active sites and involve kinetically relevant nucleophilic attack for aldol condensation and kinetically relevant enolate formation for esterification. Besides, the mechanism we propose for aldol condensation and esterification is the same for all Ti-BEA catalysts with varying silanol densities.
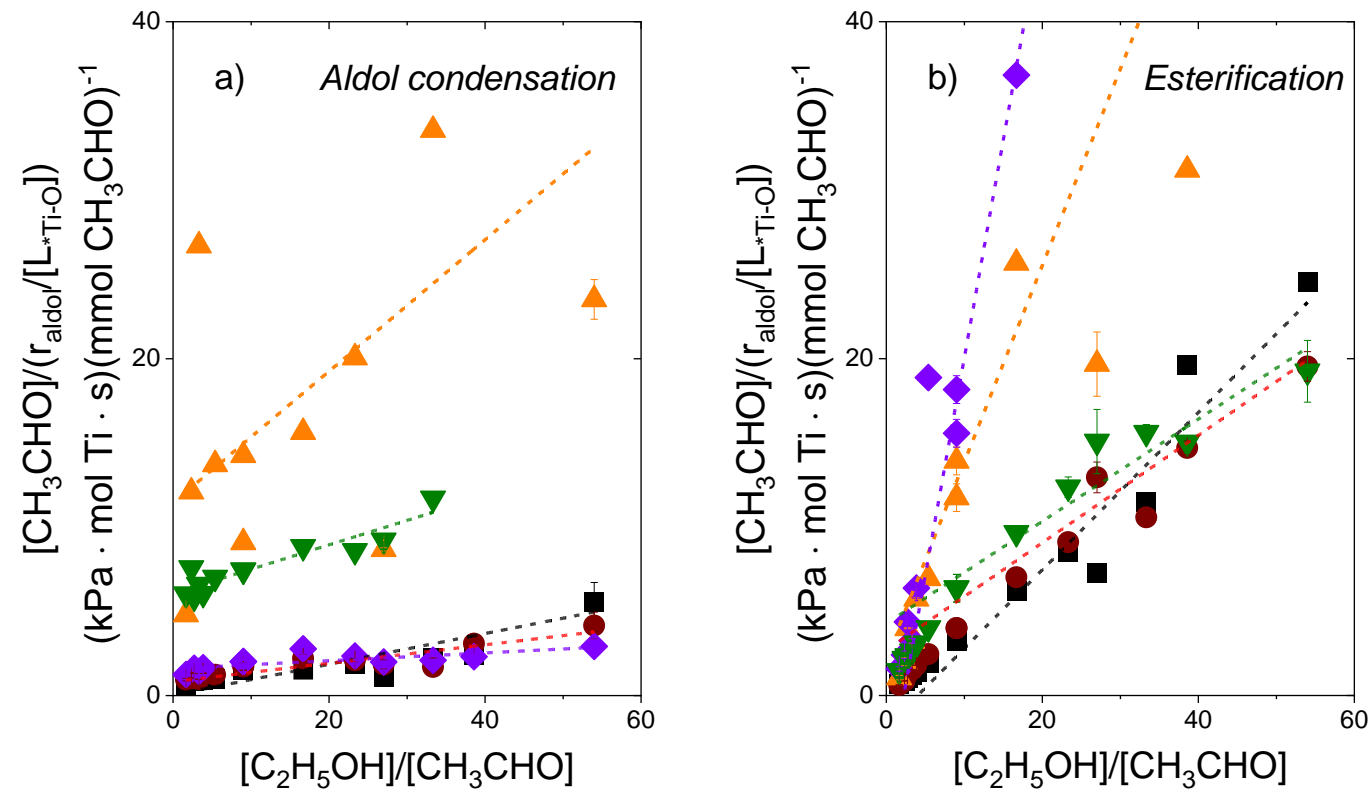

Figure S11. Linearized forms of turnover rates as functions of ratio of ethanal pressure to acetaldehyde pressure for (a) aldol condensation product formation, and (b) esterification on Ti-BEA-14 (ם), Ti-BEA-20 ( ), Ti-BEA-75 ( $\Delta$ ), 
Ti-BEA-250 $($ ) and Ti-BEA-F $(\nabla)$ at $503 \mathrm{~K}$. The dashed lines represent linear fits to equation S4-12 (Figure S13a) and equation S4-13 (Figure S13b).

\section{S.4.3. Complete Derivation of the Rate Expression for Aldol Condensation for Kinetically Relevant Reactant Adsorption}

Here, enolate formation (step 2) is the kinetically relevant step for esterification and acetaldehyde adsorption (step 1) is assumed to be the kinetically relevant step for aldol condensation. All other steps are assumed to be quasiequilibrated. $r_{\text {aldol }}$ can be expressed as:

$r_{\text {aldol }}=k_{1}\left[\mathrm{CH}_{3} \mathrm{CHO}\right]\left[*_{T i}\right]\left[*_{O}\right]$

Combining equation S4-14, S4-8 and S4-9, $r_{\text {aldol }}$ can be expressed as:

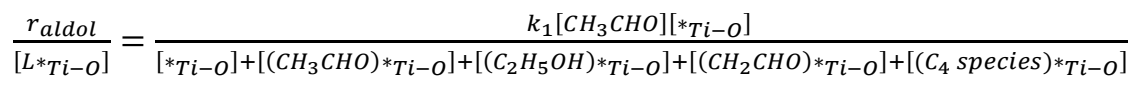

It can be assumed concentrations of $\mathrm{C}_{4}$ intermediates are negligible based on the fact that concentration of $\mathrm{C}_{2}$ species are orders of magnitude larger than $\mathrm{C}_{4}$ species at differential conversions. Combining equation S4-15 and applying quasi-equilibrated (QE) conditions on the adsorption of ethanol, $r_{\text {aldol }}$ can be simplified as:

$\frac{r_{\text {aldol }}}{\left[\text { * }_{T i-O}\right]}=\frac{k_{1}\left[\mathrm{CH}_{3} \mathrm{CHO}\right]}{1+k_{1}\left[\mathrm{CH}_{3} \mathrm{CHO}\right]+\mathrm{K}_{9}\left[\mathrm{C}_{2} \mathrm{H}_{5} \mathrm{OH}\right]+k_{1} k_{2}\left[\mathrm{CH}_{3} \mathrm{CHO}\right]}$

This rate expression would predict aldol condensation rate would at most exhibit a first order dependence on acetaldehyde pressure, which contradicts the measured power law $\left(r_{\text {aldol }}=k_{\text {app, aldol }} \frac{\left[\mathrm{CH}_{3} \mathrm{CHO}\right]^{1-1.4}}{\left[\mathrm{C}_{2} \mathrm{H}_{5} \mathrm{OH}\right]^{0.1-0.4}}\right)$ of aldol condensation. Thus, reactant adsorption is not likely to be the kinetically relevant step for aldol condensation on TiBEA catalysts.

\section{S.4.4. Complete Derivation of the Rate Expression for Aldol Condensation for Kinetically Relevant Product Desorption}

Here, enolate formation (step 2) is the kinetically relevant step for esterification and crotonaldehyde desorption (step 8 ) is assumed to be kinetically relevant for aldol condensation. All other steps are assumed to be quasi-equilibrated. $r_{\text {aldol }}$ can be expressed as:

$r_{\text {aldol }}=k_{8}\left[\left(C_{4} H_{6} O\right) *_{T i-O}\right]$ $(S 4-17)$

Equation S4-17 can be revised when step 3, 4, 5, 6 and 7 are assumed to be quasi-equilibrated: 
By implying the PSSH on $\left[H *_{o}\right]$, we find that:

$\frac{d_{\left[\mathrm{H}_{o}\right]}}{d_{t}}=k_{2} \mathrm{~K}_{1}\left[\mathrm{CH}_{3} \mathrm{CHO}\right]\left[*_{T i}\right]\left[*_{o}\right]-k_{-2}\left[\left(\mathrm{C}_{2} \mathrm{H}_{3} \mathrm{O}\right) *_{T i}\right]\left[\mathrm{H} *_{o}\right]-k_{5}\left[\mathrm{H} *_{o}\right]\left[\left(\mathrm{C}_{4} \mathrm{H}_{7} \mathrm{O}_{2}\right) *_{T i}\right]+$
$k_{-5}\left[\left(\mathrm{C}_{4} \mathrm{H}_{8} \mathrm{O}_{2}\right) *_{T i}\right]\left[*_{O}\right]-k_{11}\left[\left(\mathrm{C}_{4} \mathrm{H}_{9} \mathrm{O}_{2}\right) *_{T i}\right]\left[\mathrm{H} *_{o}\right]+k_{-11}\left[\left(\mathrm{C}_{4} \mathrm{H}_{8} \mathrm{O}_{2}\right) *_{T i}\right]\left[*_{o}\right]\left[\mathrm{H}_{2}\right]=0$

It can be assumed that all concentration of all $\mathrm{C}_{4}$ species (i.e., $\left.\left(\mathrm{C}_{4} \mathrm{H}_{7} \mathrm{O}_{2}\right) *_{\mathrm{Ti}}\right),\left(\mathrm{C}_{4} \mathrm{H}_{8} \mathrm{O}_{2}\right) *_{\mathrm{Ti}}$, and $\left.\left(\mathrm{C}_{4} \mathrm{H}_{9} \mathrm{O}_{2}\right) *_{\mathrm{Ti}}\right)$ are negligible since reactions are operated at differential conversions and pressure of reactants (e.g., $\mathrm{CH}_{3} \mathrm{CHO}_{\text {and }}$ $\left.\mathrm{C}_{2} \mathrm{H}_{5} \mathrm{OH}\right)$ are 100 times larger than that of $\mathrm{C}_{4}$ product. Equation S4-19 can be further simplified as:

$\left[H *_{O}\right]=\frac{K_{1} K_{2}\left[\mathrm{CH}_{3} \mathrm{CHO}\right]\left[*_{T i}\right]\left[*_{O}\right]}{\left[\left(\mathrm{C}_{2} \mathrm{H}_{3} \mathrm{O}\right) *_{T i}\right]}$

Equation S4-18, S4-8, S4-9 and S4-20 are combined to give the rate expression of aldol condensation:

$r_{\text {aldol }}=k_{8} K_{7} K_{6} K_{5} K_{4} K_{3} K_{1} K_{2}\left[\mathrm{CH}_{3} \mathrm{CHO}\right]^{2}\left[{ }^{*}{ }_{T i-O}\right]$

Equation S4-21, S4-1 and S4-2 give the rate expression of esterification:

$r_{\text {ester }}=K_{1}\left[\mathrm{CH}_{3} \mathrm{CHO}\right]\left[*_{T i-O}\right]\left(k_{2}-k_{8} K_{7} K_{6} K_{5} K_{4} K_{3} K_{2}\left[\mathrm{CH}_{3} \mathrm{CHO}\right]\right)$

By applying site balance (equation S4-8) to equation S4-21 and S4-22 separately, it can be derived:

$\frac{r_{\text {aldol }}}{\left[{ }^{*} \mathrm{Ti}-\mathrm{O}\right]}=\frac{k_{8} \mathrm{~K}_{7} \mathrm{~K}_{6} \mathrm{~K}_{5} \mathrm{~K}_{4} \mathrm{~K}_{3} \mathrm{~K}_{1} \mathrm{~K}_{2}\left[\mathrm{CH}_{3} \mathrm{CHO}\right]^{2}\left[{ }^{*} \mathrm{Ti-O}\right]}{\left[{ }^{*} \mathrm{Ti}-\mathrm{O}\right]+\left[\left(\mathrm{CH}_{3} \mathrm{CHO}\right){ }^{*} \mathrm{Ti}-\mathrm{O}\right]+\left[\left(\mathrm{C}_{2} \mathrm{H}_{5} \mathrm{OH}\right) *{ }^{T} \mathrm{Ti}-\mathrm{O}\right]+\left[\left(\mathrm{CH}_{2} \mathrm{CHO}\right){ }^{*} \mathrm{Ti-O}\right]+\left[\left(\mathrm{C}_{4} \text { species }\right){ }^{*} \mathrm{Ti}-\mathrm{O}\right]}$

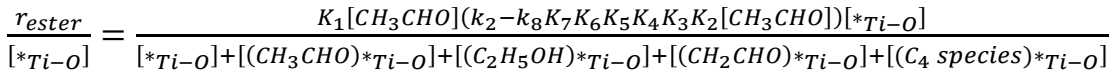

Equation S4-24 can be simplified into the measured power law for esterification $\left(r_{\text {ester }}=k_{\text {app,ester }} \frac{\left[\mathrm{CH}_{3} \mathrm{CHO}^{1}\right.}{\left[\mathrm{C}_{2} \mathrm{H}_{5} \mathrm{OH}\right]^{0}}\right)$ only when MARI are empty sites and $k_{2} \gg k_{8} K_{7} K_{6} K_{5} K_{4} K_{3} K_{2}\left[\mathrm{CH}_{3} \mathrm{CHO}\right]$. However, if MARI were assumed as empty sites, equation S4-23 can be further simplified as: 
which suggests $r_{\text {aldol }}$ would show a second order dependence on acetaldehyde pressure and be independent on ethanol pressure. This derivation contradicts the measured power law $\left(r_{\text {aldol }}=k_{\text {app,aldol }} \frac{\left[\mathrm{CH}_{3} \mathrm{CHO}\right]^{1-1.4}}{\left[\mathrm{C}_{2} \mathrm{H}_{5} \mathrm{OH}\right]^{0.1-0.4}}\right)$ of aldol condensation. Thus, product desorption is not likely to be the kinetically relevant step for aldol condensation on Ti-BEA catalysts. 


\section{S.5.0. Transition-State Theory for Measurement of Activation Enthalpies and Entropies}

\section{S.5.1. Activation Enthalpies and Entropies of Enolate Formation}

Transition state theory provides means to calculate activation enthalpy and entropy of enolate formation. According to the measured pressure dependences and transition state theory, these equations can be used to describe transition state equilibrium constants:

$\frac{r_{\text {enolate }}}{\left[*_{\text {Ti-o }}\right]}=\frac{k_{B} T}{h} K_{\text {enolate }}^{\neq}\left(\frac{\left[\mathrm{CH}_{3} \mathrm{CHO}\right]}{P^{\theta}}\right)$

where $k_{B}$ is Boltzmann's constant, $\mathrm{h}$ is Planck's constant, $\mathrm{T}$ is the temperature in Kelvin, $K_{\text {enolate }}^{\neq}$is the transition state equilibrium constant for enolate formation. $\left[\mathrm{CH}_{3} \mathrm{CHO}\right.$ ] is the partial pressures of $\mathrm{CH}_{3} \mathrm{CHO}$, and $P^{\theta}$ is the standard pressure, which is $100 \mathrm{kPa}$. The transition state equilibrium constant can be expressed in activation enthalpy and entropy through Eyring equation:

$K_{\text {enolate }}^{\neq}=e^{\frac{-\Delta H_{\text {enolate }}^{ \pm}}{R T}} e^{\frac{\Delta S_{\text {enolate }}^{ \pm}}{R}}$

where $R$ is ideal gas constant, $\Delta H_{\text {enolate }}^{\neq}$is activation enthalpy of enolate formation, and $\Delta S_{\text {enolate }}^{\neq}$is activation entropy of enolate formation. Figure $\mathbf{S 1 2}$ shows the calculated transition state equilibrium constants as a function of inverse temperature for enolate formation.

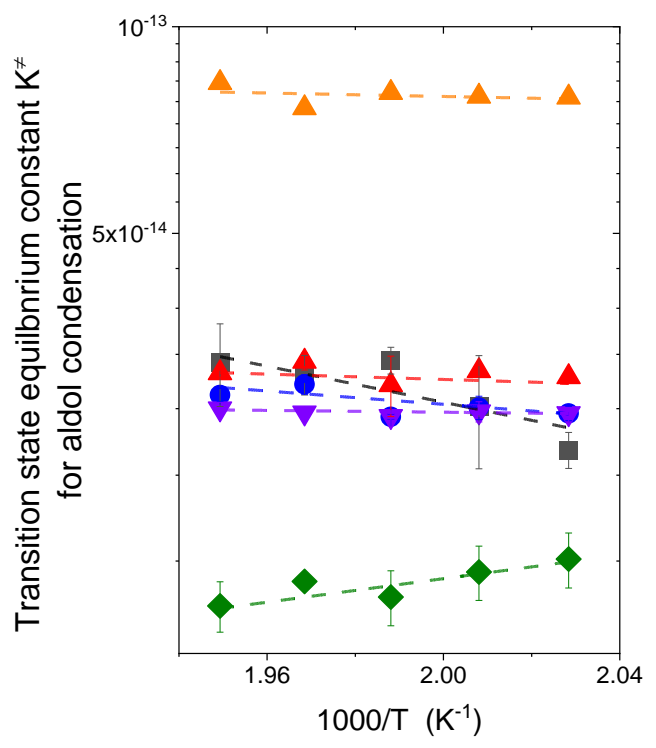

Figure S12. Transition state equilibrium constants for enolate formation ( $K_{\text {enolate }}^{\neq}$) as a function of inverse temperature $\left(0.3 \mathrm{kPa} \mathrm{CH}_{3} \mathrm{CHO}, 2.7 \mathrm{kPa} \mathrm{C}_{2} \mathrm{H}_{5} \mathrm{OH}, 15 \mathrm{kPa} \mathrm{H}\right.$, $\left.493-513 \mathrm{~K}\right)$. Dashed lines are linear fits for Eyring 


\section{S.5.2. Activation Enthalpies and Entropies of Aldol Condensation and Esterification}

Scheme S1 shows both aldol condensation and esterification pathways consume enolate intermediates. Enolate reacts with another acetaldehyde or ethanol to form aldol condensation product and esterification product, respectively. According to transition state theory, it can be assumed that enolate species (i.e., $\left.\left(\mathrm{CH}_{2} \mathrm{CHO}\right) *_{\mathrm{Ti}}\right)$ are in equilibrium with transition states that form aldol condensation or esterification intermediates in step 4 or 10, respectively. Therefore, the transition state equilibrium of aldol condensation and esterification can be expressed by:

$$
\begin{gathered}
\left(\mathrm{CH}_{2} \mathrm{CHO}\right) *_{T i}+\mathrm{CH}_{3} \mathrm{CHO}(\mathrm{g}) \stackrel{\mathrm{K}_{\text {aldol }}^{\ddagger}}{\rightleftarrows}\left(\mathrm{C}_{4} \mathrm{H}_{7} \mathrm{O}_{2}\right) *_{T i}^{\ddagger} \\
\left(\mathrm{CH}_{2} \mathrm{CHO}\right) *_{T i}+\mathrm{C}_{2} \mathrm{H}_{5} \mathrm{OH}(\mathrm{g}) \stackrel{\mathrm{K}_{\text {ester }}^{\ddagger}}{\rightleftarrows}\left(\mathrm{C}_{4} \mathrm{H}_{9} \mathrm{O}_{2}\right) *_{T i}^{\ddagger}
\end{gathered}
$$

where $K_{\text {aldol }}^{\ddagger}$ is the transition state equilibrium constant for aldol condensation and $\left(C_{4} H_{7} O_{2}\right) *_{T i}{ }^{\ddagger}$ is the transition state, $K_{\text {ester }}^{\ddagger}$ is the transition state equilibrium constant for esterification and $\left(\mathrm{C}_{4} \mathrm{H}_{10} \mathrm{O}_{2}\right) *_{T i}{ }^{\ddagger}$ is the corresponding transition state. Conventions of transition state theory and the equilibrated nature of the reactions presented in equation S5-3 and S5-4 can be expressed as:

$\frac{r_{\text {aldol }}}{\left[*_{\text {Ti-o }}\right]}=\frac{k_{B} T}{h} K_{\text {aldol }}^{\neq}\left(\frac{\left[\mathrm{CH}_{3} \mathrm{CHO}\right]}{P^{\theta}}\right)\left[\left(\mathrm{CH}_{2} \mathrm{CHO}\right) *_{T i}\right]$

$\frac{r_{\text {ester }}}{\left[*_{\text {Ti-O }}\right]}=\frac{k_{B} T}{h} K_{\text {ester }}^{\neq}\left(\frac{\left[\mathrm{C}_{2} \mathrm{H}_{5} \mathrm{OH}\right]}{P^{\theta}}\right)\left[\left(\mathrm{CH}_{2} \mathrm{CHO}\right) *_{T i}\right]$

where $k_{B}$ is Boltzmann's constant, h is Planck's constant, $\mathrm{T}$ is the temperature in Kelvin. Equilibrium constants (i.e., $K_{\text {aldol }}^{\neq}$and $\left.K_{\text {ester }}^{\neq}\right)$can be related to change in Gibbs free energy $\left(\Delta G_{i}^{\neq}\right)$that can be expressed in activation enthalpy and entropy (i.e., $\Delta G_{i}^{\neq}=\Delta H_{i}^{\neq}-T \Delta S_{i}^{\neq}$, “ $\mathrm{i}$ ” represents aldol condensation or esterification):

$K_{\text {aldol }}^{\neq}=e^{\frac{-\Delta H_{\text {aldol }}^{\neq}}{R T}} e^{\frac{\Delta S_{\text {aldol }}^{\neq}}{R}}$

$K_{\text {ester }}^{\neq}=e^{\frac{-\Delta H_{\text {ester }}^{\neq}}{R T}} e^{\frac{\Delta S_{\text {ester }}^{\neq}}{R}}$

Combining equations S5-5, S5-6, S5-7, and S5-8, 
$\frac{r_{\text {aldol }}}{r_{\text {ester }}}=e^{\frac{-\Delta H_{\text {aldol }}^{*}+\Delta H_{\text {ester }}^{*}}{R T}} e^{\frac{\Delta S_{\text {aldol }}^{\neq}-\Delta S_{\text {ester }}^{*}}{R}} \frac{\left[\mathrm{CH}_{3} \mathrm{CHO}\right]}{\left[\mathrm{C}_{2} \mathrm{H}_{5} \mathrm{OH}\right]}$

For brevity, we define $\Delta \Delta H_{\text {ester-aldol }}^{\neq}, \Delta \Delta S_{\text {ester-aldol }}^{\neq}$, and $\Delta \Delta G_{\text {ester-aldol }}^{\neq}$:

$\Delta \Delta H_{\text {ester-aldol }}^{\neq}=\Delta H_{\text {ester }}^{\neq}-\Delta H_{\text {aldol }}^{\neq}$

$(\mathrm{S} 5-10)$

$\Delta \Delta S_{\text {ester-aldol }}^{\neq}=\Delta S_{\text {ester }}^{\neq}-\Delta S_{\text {aldol }}^{\neq}$

$\Delta \Delta G_{\text {ester-aldol }}^{\neq}=\Delta \Delta H_{\text {ester-aldol }}^{\neq}-T \Delta \Delta S_{\text {ester-aldol }}^{\neq}$

Then equation S5-9 can be simplified as:

$\frac{r_{\text {aldol }}}{r_{\text {ester }}}=e^{\frac{-\Delta \Delta H_{\text {ester-aldol }}^{ \pm}}{R T}} e^{\frac{\Delta \Delta S_{\text {ester-aldol }}^{ \pm}}{R}} \frac{\left[\mathrm{CH}_{3} \mathrm{CHO}\right]}{\left[\mathrm{C}_{2} \mathrm{H}_{5} \mathrm{OH}\right]}$

By plotting $\ln \left(\frac{\left[\mathrm{C}_{2} \mathrm{H}_{5} \mathrm{OH}\right] r_{\text {aldol }}}{\left[\mathrm{CH}_{3} \mathrm{CHO}\right] r_{\text {ester }}}\right)$ versus $\frac{1}{T}$, the value of $\Delta \Delta H_{\text {ester-aldol }}^{\neq}$and $\Delta \Delta S_{\text {ester-aldol }}^{\neq}$can be obtained from slopes and intercepts respectively, which is shown in FigureS13a. Figure S13b shows the calculated $\Delta \Delta H_{\text {ester-aldol }}^{\neq}$and $\Delta \Delta S_{\text {ester-aldol }}^{\neq}$versus silanol density, and there is no monotonic trend of $\Delta \Delta H_{\text {ester-aldol }}^{\neq}$or $\Delta \Delta S_{\text {ester-aldol versus }}^{\neq}$ silanol density. Figure S14c shows $\Delta \Delta G_{\text {ester-aldol }}^{ \pm}$first decreases with silanol density, and remain similar among hydrophilic Ti-BEA catalysts, which also corroborates the results in Figure 8b. 

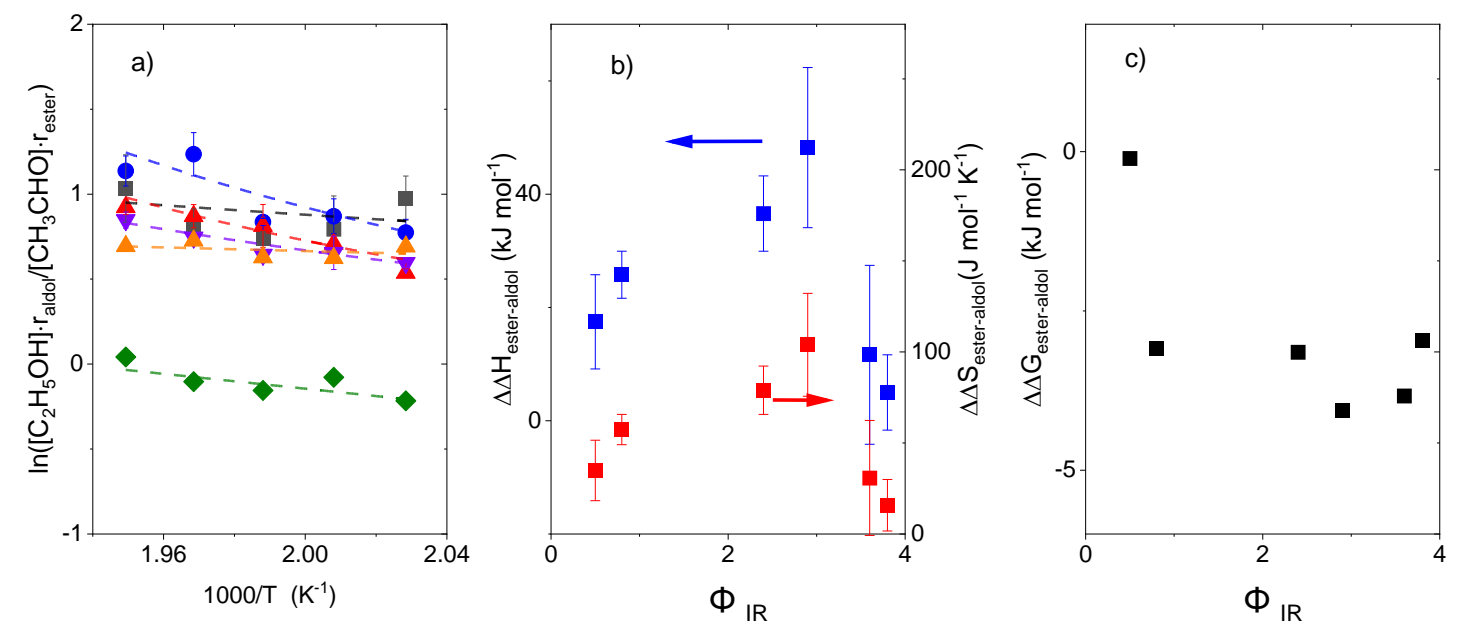

Figure S13. a) $\ln \left(\frac{\left[\mathrm{C}_{2} \mathrm{H}_{5} \mathrm{OH}\right] r_{\text {aldol }}}{\left[\mathrm{CH}_{3} \mathrm{CHO}\right] r_{\text {ester }}}\right)$ as a function of inverse temperature $\left(0.3 \mathrm{kPa} \mathrm{CH}_{3} \mathrm{CHO}, 2.7 \mathrm{kPa} \mathrm{C}_{2} \mathrm{H}_{5} \mathrm{OH}, 15 \mathrm{kPa}\right.$ $\left.\mathrm{H}_{2}, 493-513 \mathrm{~K}\right)$. Dashed lines are linear fits for equation S5-9 and S5-10. Symbols are used for different Ti-BEA :

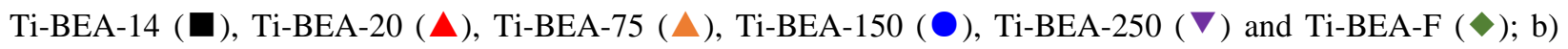
Calculated $\Delta \Delta H_{\text {ester-aldol }}^{\neq}(\square)$ and $\Delta \Delta S_{\text {ester-aldol }}^{\neq}(\square)$ as a functions of silanol density ( $\left.\Phi_{\mathrm{IR}}\right)$; c) Calculated $\Delta \Delta G_{\text {ester-aldol }}^{\neq}(\boldsymbol{\square})$ as a functions of silanol density $\left(\Phi_{\mathrm{IR}}\right)$ at $503 \mathrm{~K}$; 


\section{S.6.0. Explaining the Isotope Effects of Aldol Condensation and Esterification on Ti-BEA Catalysts}

Table 3 and Figure 4 in section 3.2.2 shows rates of aldol condensation and esterification on Ti-BEA change when $\mathrm{CD}_{3} \mathrm{CDO}$ replaces $\mathrm{CH}_{3} \mathrm{CHO}$ at otherwise identical reaction conditions. Equation 4-2 suggests enolate formation rate (i.e., $r_{\text {enolate }}$ ) equals the sum of aldol condensation rate (i.e., $r_{\text {aldol }}$ ) and esterification rate (i.e., $r_{\text {ester }}$ ), and Table S1 show the change in rates of enolate formation, aldol condensation and esterification when $\mathrm{CH}_{3} \mathrm{CHO}$ is replaced with $\mathrm{CD}_{3} \mathrm{CDO}$ at the same conditions $\left(0.3 \mathrm{kPa} \mathrm{CH}_{3} \mathrm{CHO}\right.$ or $\left.\mathrm{CD}_{3} \mathrm{CDO}, 2.7 \mathrm{kPa} \mathrm{C}_{2} \mathrm{H}_{5} \mathrm{OH}, 15 \mathrm{kPa} \mathrm{H}_{2}, 503 \mathrm{~K}\right)$.

Table S1. Rate ratio of enolate formation, aldol condensation and esterification upon isotope exchange

\begin{tabular}{|c|c|c|c|}
\hline Ti-BEA & $\frac{r_{\text {enolate }, H} \mathrm{a}}{r_{\text {enolate }, \mathrm{D}}}$ & $\frac{r_{\text {ester }, \mathrm{H}} \mathrm{b}}{r_{\text {ester }, \mathrm{D}}}$ & $\frac{r_{\text {aldol }, \mathrm{H}} \mathrm{c}}{r_{\text {aldol, }}}$ \\
\hline Ti-BEA-14 & 1.9 & $2.9 \pm 0.4$ & $0.9 \pm 0.2$ \\
\hline Ti-BEA-20 & 2.0 & $3.1 \pm 0.4$ & $0.8 \pm 0.1$ \\
\hline Ti-BEA-75 & 3.9 & $5.6 \pm 0.3$ & $0.9 \pm 0.1$ \\
\hline Ti-BEA-150 & 2.0 & $3.0 \pm 0.3$ & $0.9 \pm 0.1$ \\
\hline Ti-BEA-250 & 3.2 & $5.2 \pm 0.3$ & $0.7 \pm 0.1$ \\
\hline Ti-BEA-F & 2.4 & $2.6 \pm 0.7$ & $0.9 \pm 0.1$ \\
\hline
\end{tabular}

${ }^{\mathrm{a}} r_{\text {enolate }, H}$ represents enolate formation rate at $0.3 \mathrm{kPa} \mathrm{CH}_{3} \mathrm{CHO} ; r_{\text {enolate }, D}$ represents enolate formation rate at $0.3 \mathrm{kPa} \mathrm{CD}_{3} \mathrm{CDO}$.

${ }^{\mathrm{b}} r_{\text {ester,H }}$ represents esterification rate at $0.3 \mathrm{kPa} \mathrm{CH} \mathrm{CHO}_{3} r_{\text {ester }, D}$ represents esterification rate at $0.3 \mathrm{kPa} \mathrm{CD}{ }_{3} \mathrm{CDO}$.

${ }^{\mathrm{c}} r_{\text {aldol,H }}$ represents aldol condensation rate at $0.3 \mathrm{kPa} \mathrm{CH} \mathrm{CHO}_{3} \mathrm{CHO} r_{\text {aldol, }}$ represents aldol condensation rate at $0.3 \mathrm{kPa} \mathrm{CD}_{3} \mathrm{CDO}$.

The values of the kinetic isotope effects suggest enolate formation occurs irreversibly and is a kinetically relevant step for ester formation but that a subsequent process controls rates of aldol condensation on Ti-BEA.

Following Section S4, rates of enolate formation, aldol condensation and esterification can be expressed as:

$$
\begin{array}{lr}
r_{\text {enolate }}=k_{2} \mathrm{~K}_{1}\left[\mathrm{CH}_{3} \mathrm{CHO}\right]\left[*_{T i}\right]\left[*_{O}\right] & (S 6-1) \\
r_{\text {aldol }}=k_{4}\left[\left(\mathrm{C}_{2} \mathrm{H}_{3} \mathrm{O}\right) *_{T i}\right] K_{3}\left[\mathrm{CH}_{3} \mathrm{CHO}\right] & (S 6-2) \\
r_{\text {ester }}=k_{10} \mathrm{~K}_{9}\left[\mathrm{C}_{2} \mathrm{H}_{5} \mathrm{OH}\right]\left[\left(\mathrm{C}_{2} \mathrm{H}_{3} \mathrm{O}\right) *_{T i}\right] & (S 6-3)
\end{array}
$$

Both aldol condensation and esterification consume enolate intermediates, and rate of enolate formation equals sum of rate of aldol condensation and esterification, which suggests:

$r_{\text {enolate }}=r_{\text {ester }}+r_{\text {aldol }}$

Equation S4-5 shows coverage of enolate when pseudo steady-state hypothesis is applied for enolate species:

$\left[\left(\mathrm{C}_{2} \mathrm{H}_{3} \mathrm{O}\right) *_{T i}\right]=\frac{k_{2} \mathrm{~K}_{1}\left[\mathrm{CH}_{3} \mathrm{CHO}\right]\left[*_{T i}\right]\left[*_{O}\right]}{k_{4} K_{3}\left[\mathrm{CH}_{3} \mathrm{CHO}\right]+k_{10} \mathrm{~K}_{9}\left[\mathrm{C}_{2} \mathrm{H}_{5} \mathrm{OH}\right]}$

For enolate formation upon isotope exchange from $\mathrm{CH}_{3} \mathrm{CHO}$ to $\mathrm{CD}_{3} \mathrm{CDO}$ :

$\frac{r_{\text {enolate }, H}}{r_{\text {enolate }, D}}=\frac{k_{2 \mathrm{H}} K_{1 \mathrm{H}}\left[\mathrm{CH}_{3} \mathrm{CHO}\right]\left[*_{T i}\right]\left[*_{O}\right]}{k_{2 \mathrm{D}} K_{1 \mathrm{D}}\left[C D_{3} C D O\right]\left[*_{T i}\right]\left[*_{O}\right]}$

where $K_{1 \mathrm{H}}$ represents adsorption constant of $\mathrm{CH}_{3} \mathrm{CHO}, K_{1 \mathrm{D}}$ represents adsorption constant of $\mathrm{CD}_{3} \mathrm{CDO}, k_{2 \mathrm{H}}$ represents rate constant for deprotonation of $\mathrm{CH}_{3} \mathrm{CHO}, k_{2 \mathrm{D}}$ represents rate constant for deprotonation of $\mathrm{CD}_{3} \mathrm{CDO}$, $\left[*_{T i}\right]$ and $\left[{ }_{0}\right]$ represent the numbers of unoccupied Ti and $\mathrm{O}$ sites, respectively.

It can be assumed that isotope exchange has no influence on adsorption constant (i.e., $K_{1 \mathrm{H}}=K_{1 \mathrm{D}}$ ), then 
$\frac{r_{\text {enolate } H}}{r_{\text {enolate } D}}=\frac{k_{2 \mathrm{H}}}{k_{2 \mathrm{D}}}$

$(S 6-7)$

Table S1 suggests normal kinetic isotope effect is observed on all Ti-BEA catalysts (i.e., $\frac{r_{\text {enolate,H }}}{r_{\text {enolate, }}}=\frac{k_{2 \mathrm{H}}}{k_{2 \mathrm{D}}}>1$ ), and enolate formation is a rate determining step.

Enolate coverage (equations S6-5) can change when $\mathrm{CD}_{3} \mathrm{CDO}$ replaces $\mathrm{CH}_{3} \mathrm{CHO}$, and the ratio is

$\frac{\left[\left(C_{2} H_{3} O\right) *_{T i}\right]}{\left[\left(C_{2} D_{3} O\right) *_{T i}\right]}=\left(\frac{k_{2 \mathrm{H}} K_{1 \mathrm{H}}\left[C H_{3} C H O\right]}{k_{2 \mathrm{D}} K_{1 \mathrm{D}}\left[C D_{3} C D O\right]}\right)\left(\frac{k_{4 \mathrm{D}} K_{3 \mathrm{D}}\left[C D_{3} C D O\right]+k_{10 \mathrm{D}} K_{9 \mathrm{H}}\left[C_{2} H_{5} O H\right]}{k_{4 \mathrm{H}} K_{3 \mathrm{H}}\left[C H_{3} C H O\right]+k_{10 \mathrm{H}} K_{9 \mathrm{H}}\left[C_{2} H_{5} O H\right]}\right)$

where $K_{3 \mathrm{H}}$ represents adsorption constant of $\mathrm{CH}_{3} \mathrm{CHO}, K_{3 \mathrm{D}}$ represents adsorption constant of $\mathrm{CD}_{3} \mathrm{CDO}, K_{9 \mathrm{H}}$ represents adsorption constant of $\mathrm{C}_{2} \mathrm{H}_{5} \mathrm{OH}$. We assume there is no isotope effect on adsorption of $\mathrm{CH}_{3} \mathrm{CHO}$ and $\mathrm{C}_{2} \mathrm{H}_{5} \mathrm{OH}$ (i.e., $\left.K_{1 \mathrm{H}}=K_{1 \mathrm{D}}, K_{3 \mathrm{H}}=K_{3 \mathrm{D}}\right)$, and the pressures of reactants remain fixed upon isotope substitution $(0.3 \mathrm{kPa}$ $\mathrm{CH}_{3} \mathrm{CHO}$ or $\left.\mathrm{CD}_{3} \mathrm{CDO}, 2.7 \mathrm{kPa} \mathrm{C}_{2} \mathrm{H}_{5} \mathrm{OH}\right)$. Then equation $\mathrm{S} 6-8$ can be simplified as:

$\frac{\left[\left(C_{2} H_{3} O\right) *_{T i}\right]}{\left[\left(C_{2} D_{3} O\right) *_{T i}\right]}=\left(\frac{k_{2 \mathrm{H}}}{k_{2 \mathrm{D}}}\right)\left(\frac{k_{4 \mathrm{D}}+9 \frac{K_{9 \mathrm{H}}}{K_{3 \mathrm{H}}} k_{10 \mathrm{D}}}{k_{4 \mathrm{H}}+9 \frac{K_{9 \mathrm{H}}}{K_{3 \mathrm{H}}} k_{10 \mathrm{H}}}\right)$

From kinetic isotope effect on enolate formation, it has been shown the ratio of the rate constants $\frac{k_{2 \mathrm{H}}}{k_{2 \mathrm{D}}}$ is greater than unity (i.e., $\frac{k_{2 \mathrm{H}}}{k_{2 \mathrm{D}}}>1$ ). Step 4 corresponds to aldol addition from enolate to $\mathrm{CH}_{3} \mathrm{CHO}$, and it requires carbon hybridization of $\mathrm{CH}_{3} \mathrm{CHO}$ changes from $\mathrm{sp}^{2}$ to $\mathrm{sp}^{3}$, which potentially suggests the ratio of $\frac{k_{4 \mathrm{H}}}{k_{4 \mathrm{D}}}$ is less than unity (i.e., $\frac{k_{4 \mathrm{H}}}{k_{4 \mathrm{D}}}<1$ ). Step 10 is nucleophilic attack from enolate to $\mathrm{C}_{2} \mathrm{H}_{5} \mathrm{OH}$, and there is no change in carbon hybridization of $\mathrm{C}_{2} \mathrm{H}_{5} \mathrm{OH}$. Thus, it can be assumed that $\frac{k_{10 \mathrm{H}}}{k_{10 \mathrm{D}}}$ is approximately one (i.e., $\frac{k_{10 \mathrm{H}}}{k_{10 \mathrm{D}}} \sim 1$ ). Based on all these assumptions, enolate coverage would decrease when $\mathrm{CD}_{3} \mathrm{CDO}$ replaces $\mathrm{CH}_{3} \mathrm{CHO}$ since all terms in the numerator of equation S69 tend to be larger than or equal to the corresponding terms in the denominator, which means:

$\frac{\left[\left(C_{2} H_{3} O\right) *_{T i}\right]}{\left[\left(C_{2} D_{3} O\right) *_{T i}\right]}=\left(\frac{k_{2 \mathrm{H}}}{k_{2 \mathrm{D}}}\right)\left(\frac{k_{4 \mathrm{D}}+9 \frac{K_{9 \mathrm{H}}}{K_{3 \mathrm{H}}} k_{10 \mathrm{D}}}{k_{4 \mathrm{H}}+9 \frac{K_{9 \mathrm{H}}}{K_{3 \mathrm{H}}} k_{10 \mathrm{H}}}\right)>1$

For aldol condensation upon isotope exchange from $\mathrm{CH}_{3} \mathrm{CHO}$ to $\mathrm{CD}_{3} \mathrm{CDO}$, the rate ratio can be expressed as:

$\frac{r_{\text {aldol }, H}}{r_{\text {aldol }, D}}=\left(\frac{k_{4 H} K_{3 H}\left[C H_{3} C H O\right]}{k_{4 D} K_{3 D}\left[C D_{3} C D O\right]}\right)\left(\frac{\left[\left(C_{2} H_{3} O\right) *_{T i}\right]}{\left[\left(C_{2} D_{3} O\right) *_{T i}\right]}\right)$

We have discussed that ratio of $\frac{k_{4 \mathrm{H}}}{k_{4 \mathrm{D}}}$ is less than unity (i.e., $\frac{k_{4 \mathrm{H}}}{k_{4 \mathrm{D}}}<1$ ) because step 4 requires carbon hybridization of $\mathrm{CH}_{3} \mathrm{CHO}$ changes from $\mathrm{sp}^{2}$ to $\mathrm{sp}^{3}$. Enolate coverage would decrease when $\mathrm{CD}_{3} \mathrm{CDO}$ replaces $\mathrm{CH}_{3} \mathrm{CHO}$ (i.e., $\left.\frac{\left[\left(C_{2} H_{3} O\right) * T i\right]}{\left[\left(C_{2} D_{3} O\right) *_{T i}\right]}>1\right)$. Thus, it is hard to determine precisely what $\frac{r_{\text {aldol, } H}}{r_{\text {aldol, } D}}$ would be. Our results show ratios of rates for aldol addition upon isotope substitution are slightly less than one $\left(\frac{r_{\text {aldol, } H}}{r_{\text {aldol,D }}}=0.9 \pm 0.1\right)$, which suggests upon isotope exchange, enolate coverage decreases, but rate constant of enolate addition to acetaldehyde increases (i.e., $\left.\frac{k_{4 \mathrm{H}}}{k_{4 \mathrm{D}}}<1\right)$. These are two trade-off effects, and our results suggest increase in rate constant $\left(k_{4}\right)$ outweighs the effect from enolate coverage.

For esterification upon isotope exchange from $\mathrm{CH}_{3} \mathrm{CHO}$ to $\mathrm{CD}_{3} \mathrm{CDO}$, the rate ratio can be expressed as: 
$\frac{r_{\text {ester }, H}}{r_{\text {ester }, D}}=\left(\frac{k_{10 H} K_{9 H}\left[C_{2} H_{5} O H\right]}{k_{10 D} K_{9 H}\left[C_{2} H_{5} O H\right]}\right)\left(\frac{\left[\left(C_{2} H_{3} O\right) *_{T i}\right]}{\left[\left(C_{2} D_{3} O\right) *_{T i}\right]}\right)$

The discussion above suggests $\frac{k_{10 \mathrm{H}}}{k_{10 \mathrm{D}}}$ is approximately one (i.e., $\frac{k_{10 \mathrm{H}}}{k_{10 \mathrm{D}}} \sim 1$ ) because step 10 is nucleophilic attack from enolate to $\mathrm{C}_{2} \mathrm{H}_{5} \mathrm{OH}$, and there is no change in carbon hybridization of $\mathrm{C}_{2} \mathrm{H}_{5} \mathrm{OH}$. Besides, enolate coverage would decrease when $\mathrm{CD}_{3} \mathrm{CDO}$ replaces $\mathrm{CH}_{3} \mathrm{CHO}$ (i.e., $\frac{\left[\left(C_{2} H_{3} O\right) *_{T i}\right]}{\left[\left(C_{2} D_{3} O\right) *_{T i}\right]}>1$ ). It can be derived that esterification rate will decrease when $\mathrm{CD}_{3} \mathrm{CDO}$ replaces $\mathrm{CH}_{3} \mathrm{CHO}$ (i.e., $\frac{r_{e s t e r, H}}{r_{e s t e r, D}}>1$ ), which corresponds to the results in Table $\mathbf{S 2}$.

Overall, the measured kinetic isotope effects when $\mathrm{CD}_{3} \mathrm{CDO}$ replaces $\mathrm{CH}_{3} \mathrm{CHO}$ are consistent with the proposed mechanism that enolate formation occurs irreversibly and is a kinetically relevant step for esterification but a consecutive process controls rates of aldol condensation on Ti-BEA.

\section{Reference:}

1. $\quad$ Bregante, D. T.; Johnson, A. M.; Patel, A. Y.; Ayla, E. Z.; Cordon, M. J.; Bukowski, B. C.; Greeley, J.; Gounder, R.; Flaherty, D. W., Cooperative Effects between Hydrophilic Pores and Solvents: Catalytic Consequences of Hydrogen Bonding on Alkene Epoxidation in Zeolites. Journal of the American Chemical Society 2019, 141 (18), 7302-7319.

2. $\quad$ Mihailova, B.; Valtchev, V.; Mintova, S.; Faust, A. C.; Petkov, N.; Bein, T., Interlayer stacking disorder in zeolite beta family: a Raman spectroscopic study. Physical Chemistry Chemical Physics 2005, 7 (14), 2756-2763.

3. Signorile, M.; Crocellà, V.; Damin, A.; Rossi, B.; Lamberti, C.; Bonino, F.; Bordiga, S., Effect of Ti Speciation on Catalytic Performance of TS-1 in the Hydrogen Peroxide to Propylene Oxide Reaction. The Journal of Physical Chemistry C 2018, 122 (16), 9021-9034.

4. $\quad$ Song, W.; Xiong, G.; Long, H.; Jin, F.; Liu, L.; Wang, X., Effect of treatment with different bases on the catalytic properties of TS-1/SiO2 extrudates in propylene epoxidation. Microporous and Mesoporous Materials 2015, $212,48-55$.

5. Inagaki, S.; Nakatsuyama, K.; Saka, Y.; Kikuchi, E.; Kohara, S.; Matsukata, M., Elucidation of MediumRange Structure in a Dry Gel-Forming *BEA-Type Zeolite. The Journal of Physical Chemistry C 2007, 111 (28), 10285-10293.

6. $\quad$ Scarano, D.; Zecchina, A.; Bordiga, S.; Geobaldo, F.; Spoto, G.; Petrini, G.; Leofanti, G.; Padovan, M.; Tozzola, G., Fourier-transform infrared and Raman spectra of pure and Al-, B-, Ti- and Fe-substituted silicalites: stretching-mode region. Journal of the Chemical Society, Faraday Transactions 1993, 89 (22), 4123-4130.

7. Tomlinson, S. R.; McGown, T.; Schlup, J. R.; Anthony, J. L., Infrared Spectroscopic Characterization of CIT-6 and a Family of *BEA Zeolites. International Journal of Spectroscopy 2013, 2013, 961404.

8. Wang, S.; Iglesia, E., Substituent Effects and Molecular Descriptors of Reactivity in Condensation and Esterification Reactions of Oxygenates on Acid-Base Pairs at $\mathrm{TiO} 2$ and $\mathrm{ZrO} 2$ Surfaces. The Journal of Physical Chemistry C 2016, 120 (38), 21589-21616. 